\title{
Assessing the relevance of atmospheric heavy metal deposition with regard to ecosystem integrity and human health in Germany
}

\author{
Angela Schlutow ${ }^{1}$, Winfried Schröder ${ }^{2^{*}}$ (D) and Thomas Scheuschner ${ }^{3}$
}

\begin{abstract}
Background: The critical values for heavy metal fluxes for protecting the human health and ecosystem's integrity in Germany, especially the Federal Immission Control Act (BImSchG in Gesetz zum Schutz vor schädlichen Umwelteinwirkungen durch Luftverunreinigungen, Geräusche, Erschütterungen und ähnliche Vorgänge (BundesImmissionsschutzgesetz-BImSchG), 1974/2020) with its implementing ordinances (especially the 39th BImSchV in Neununddreißigste Verordnung zur Durchführung des Bundes-Immissionsschutzgesetzes Verordnung über Luftqualitätsstandards und Emissionshöchstmengen vom 2. August 2010, zuletzt geändert durch Art. 2 V v. 18.7.2018I 1222, 2010, 2018), the Federal Soil Protection Ordinance (BBodSchV in Bundes-Bodenschutz- und Altlastenverordnung (BBodSchV) (GBBI. I S. 1554 vom 12. Juli 1999, zuletzt durch Artikel 3 Absatz 4 der Verordnung vom 27. September 2017 (BGBI. I S. 3465) ge-ändert, 1999/2015) and the Technical Instructions on Air Quality Control (Luft in Erste Allgemeine Verwaltungsvorschrift zum Bundes-Immissionsschutzgesetz (Technische Anleitung zur Reinhaltung der Luft - TA Luft), 2002), were analysed, assessed with regard to the possibilities and applicability of the risk assessment, and were prepared for evaluation in comparison to the respective atmospheric deposition modelled with the chemical transport model LOTOS-EUROS. For a comparison of the critical values, the critical loads for cadmium, lead and mercury inputs were updated for Germany on a scale of 1:1 Mio, and critical loads for additional heavy metals (arsenic, copper, zinc, chromium and nickel) were computed, respectively. Due to the methodological differences of their derivation, the critical values of the individual regulations are only conditionally comparable to one another and to the critical loads. Sometimes major differences exist due to different levels of protection, various protective goods and the effect relationship. Only with the critical load calculations, inputs and outputs can be balanced.

Results: For two unregulated metals (thallium and vanadium) a preliminary rough estimate of the risk of inputs in the receptors was provided as a calculated balance for in- and acceptable outputs. The uncertainty analysis shows, that the highest deviations occurred in the metal contents in plants used to calculate the output through the harvesting of the biomass. The critical load calculation has the highest sensitivity to changes in the $\mathrm{pH}$ value. The critical loads for heavy metal fluxes for protecting the human health $\left(\mathrm{CL}(\mathrm{M})_{\text {drink }}\right)$ and ecosystem's integrity $\left.\mathrm{CL}(\mathrm{M})_{\text {eco }}\right)$ for arsenic, nickel, zinc and chromium were not exceeded in Germany for 2009-2011. CL(M) drink and CL(M)eco are exceeded by $\mathrm{Hg}$ and $\mathrm{Pb}$ inputs, especially in the low rainfall regions of Germany (Brandenburg, lowlands of Saxony-Anhalt, Leipzig Bay, Ruhr valley) with wood vegetation; in addition $\mathrm{CL}(\mathrm{Cu})_{\text {eco }}$ is exceeded by copper deposition 2010 in the
\end{abstract}

\footnotetext{
*Correspondence: winfried.schroeder@uni-vechta.de

${ }^{2}$ Lehrstuhl für Landschaftsökologie, Universität Vechta, Postfach 1553,

49364 Vechta, Germany

Full list of author information is available at the end of the article
}

\section{Springer Open}

(c) The Author(s) 2020. This article is licensed under a Creative Commons Attribution 4.0 International License, which permits use, sharing, adaptation, distribution and reproduction in any medium or format, as long as you give appropriate credit to the original author(s) and the source, provide a link to the Creative Commons licence, and indicate if changes were made. The images or other third party material in this article are included in the article's Creative Commons licence, unless indicated otherwise in a credit line to the material. If material is not included in the article's Creative Commons licence and your intended use is not permitted by statutory regulation or exceeds the permitted use, you will need to obtain permission directly from the copyright holder. To view a copy of this licence, visit http://creativeco mmons.org/licenses/by/4.0\%. 
area surrounding Berlin and in the Ruhr valley. The critical loads for cadmium for the protection of drinking water $\mathrm{CL}(\mathrm{Cd})_{\text {drink }}$ and for the protection of human food from wheat products $\mathrm{CL}(\mathrm{Cd})_{\text {food }}$ are not exceeded in the German data set due to atmospheric deposition in 2010, but in the worst-case scenario the maximum atmospheric deposition in 2010 could exceeded the lowest $\mathrm{CL}(\mathrm{Cd})_{\text {drink }}$ and $\mathrm{CL}(\mathrm{Cd})_{\text {food }}$.

Conclusions: That assessment of risks was based on deposition from the atmosphere, which represents only a fraction of the inputs compared to the inputs from the use of fertilisers and other sources. This study suggests the conclusive recommendation to methodically deepen and broaden the assessment and evaluation of atmospheric deposition. This is especially true for the spatial validation and specification of exposure for ecosystem types.

Keywords: Heavy metals, Assessment values of heavy metals, Critical loads for the protection of human health, Critical loads for the protection of ecosystems

\section{Background}

Besides natural geochemical processes, anthropogenic sources contribute to the input of heavy metals into the soil, plants and groundwater. These are in particular heavy metal depositions from emissions of dust and aerosols from industrial and power generation plants, the use of metal-contaminated mineral phosphate fertilisers and sewage sludge in agriculture, tyre wear in road traffic, surface runoff from mining waste dumps contaminated with heavy metals, waste water irrigation in agriculture, etc. $[1,2]$. However, the present study is mainly limited to the atmospheric input of heavy metals into soil, plants and groundwater.

The extent and temporal and spatial distribution of heavy metal inputs from the atmosphere can be determined with technical and biological collectors such as mosses and chemical transport models (EMEP [3], LOTOS-EUROS) [4-6]. The aim of this contribution was to assess heavy metal deposition rates in terms of their effects and compliance with legal requirements and environmental quality objectives. As heavy metals can be transported in the atmosphere over long distances and across national borders, both national and international regulations and assessment methods have to be considered thereby.

The risk potential for human health of increased concentrations of heavy metals in air, food and drinking water has been known for a long time, as has that of heavy metal enrichment for aquatic and terrestrial ecosystems. In order to prevent harmful effects and avert dangers, the German Federal Immission Control Act [7], the Federal Immission Control Acts (BImSchV) and the Technical Instructions Air [8], regulate the limitation of heavy metal emission (lead, cadmium, mercury, arsenic, nickel) and immission or deposition. The 39th Federal

\footnotetext{
${ }^{1}$ http://www.umweltbundesamt.de/themen/luft/regelungen-strategien/luftr einhaltung-in-der-eu.
}

Immission Control Act [9] implements ${ }^{1}$ the EU Directives 2008/50/EC [10, 11] and 2004/107/EC [12].

At the end of 2013, the EU presented a new package of measures for clean air in Europe to update existing legislation. The objective is to further reduce emissions of air pollutants in order to reduce or eliminate impacts on human health and the environment. The package includes a "Clean Air for Europe" programme, the initial aim of which is to ensure that existing objectives are met. In addition, new air quality targets for 2020 and 2030 have also been formulated. The objective of this strategy for 2020 is to reduce air pollution to levels that no longer have a significant impact on human health or the environment. The assessment of the relevance of heavy metals deposition presented in this article was also intended to evaluate whether this objective can be achieved with the existing regulations.

The European Directive 2008/50/EC prescribes a limit value for lead in PM10 dust of $500 \mathrm{ng} / \mathrm{m}^{3}$. This limit value has been in force since 2005. Directive 2004/107/EC contains target values for nickel, arsenic and cadmium. The target values correspond to those of the EU position paper 2000 [13]. When setting EU limit and target values, not only health considerations, but also technical feasibility and economic effects are taken into account. Article 21(5) of Directive 2010/75/EU [14] obliges EU Member States to adapt the permit requirements for the construction or modification of a pollutant-emitting installation to new or revised BAT (= best available techniques) conclusions. The European Commission has been publishing new BAT reference documents on a regular basis since 2001.

Another international regulation binding under international law is the Heavy Metals Protocol of the Convention on Long-range Transboundary Air Pollution (CLRTAP, also known as the Århus Protocol on Heavy Metals). It came into force at the end of 2003 and was revised in December 2012 and adapted to the modern requirements of industrial plants. In this protocol, emissions of $\mathrm{Pb}, \mathrm{Cd}, \mathrm{Hg}$ into the air are regulated, e.g. by 
technical standards for industries that emit heavy metals. It also regulates the use of lead in petrol or the use of cadmium and mercury in certain products. In the Convention on Long-range Transboundary Air Pollution (CLRTAP), the impact assessment of heavy metal inputs is carried out using the critical loads approach, which has long been proven for the assessment of inputs of eutrophic nitrogen or acid into ecosystems. This method enables a comprehensive risk assessment for large areas as, e.g. for Germany, the EU or the EMEP region [15]. The determination of deposition required for the classification of the risk of exceeding the critical loads is carried out by measurement and modelling in the EMEP programme [4] and is supported by biomonitoring with mosses [6].

The German Ordinance on Air Quality Standards and Emission Ceilings of 2 August 2010, last amended in 2018 [9] serves to implement European requirements and their national implementation. It contains immission target values for arsenic, cadmium and nickel for the protection of human health and the environment (as an average of a calendar year). The responsible immission control authorities of the Länder are obliged to carry out periodic measurements of heavy metal concentrations in the air. If these are exceeded regionally, the authorities are obliged to draw up air pollution control plans. In practice, this initially involves a close-meshed grid measurement. The emission sources are determined on this basis. Clean air plans to reduce emissions are then drawn up and appropriate agreements are made with plant operators who have been identified as the main sources. For industrial installations covered by Directive 2008/1/EC [11], this means that the best available techniques (BAT) within the meaning of Article 2(12) of that Directive must be applied. If an operator refuses or fails to comply with a voluntary agreement, the competent authority shall impose a subsequent order. Within the framework of the precautionary obligations under Article 5 para. 1 No. 2 of the Federal Immission Control Act, the main point is that installations must retrofit to the state of the art (in accordance with the relevant BAT reference document). If the state of the art changes after the issue of a permit, a subsequent order pursuant to $\$ 17$ para. 1 sentence $1 \mathrm{BImSchG}$ may require that the state of the art be implemented in plants that have already been granted a permit, for example by installing filter systems or similar. If the operator of a plant subject to approval does not comply with a subsequent order, the competent authority may prohibit operation in whole or in part until the subsequent order is complied with, if a violation of the subsequent order causes an immediate danger to human health or constitutes an immediate significant danger to the environment ( $\$ 20$ (1) BImmSchG).
The Federal Soil Protection and Contaminated Sites Ordinance of 12 July 1999, last amended in 2017, (BBod$\mathrm{SchV}$ ) regulates the planned investigation of harmful soil changes and their evaluation by the competent authorities on the basis of precautionary, test and measure values or permissible deposition rates. Concrete indications that give rise to sufficient suspicion of harmful soil changes or contaminated sites are generally available if investigations show that test values are exceeded. In this case, a detailed investigation should determine whether hazards arise from spatially limited accumulations of pollutants within a suspected area and whether and how a demarcation of uncontaminated areas is advisable. If a test value is exceeded at the site of sampling, it shall be determined in each individual case whether the pollutant concentration in the leachate at the site of assessment exceeds the test value. In order to assess the risks to groundwater from suspected areas, a leachate prognosis shall be prepared in order to estimate and evaluate in each individual case to what extent it can be expected that the pollutant concentration in the leachate will exceed the test value at the place of assessment. The place of assessment is the area of transition from the unsaturated to the saturated zone. Insofar as harmful soil changes and contaminated sites are present in the water-saturated soil zone, they shall be assessed with regard to a hazard to groundwater in accordance with water law regulations. The geogenically conditioned background situation of the respective groundwater region must be taken into account when applying the test values. The results of the detailed investigation are to be evaluated with regard to the extent to which measures are necessary, taking into account the circumstances of the individual case, in particular on the basis of measure values. In the event that measure values are locally exceeded, the BBodSchV contains requirements for danger prevention by decontamination and safety measures, protective and restrictive measures for individual existing installations. The procedures that then follow correspond to those according to BImSchV.

In addition to the precautionary regulations on immission control, soil protection regulations are relevant in Germany which limit the input of heavy metals including atmospheric deposition if the concentrations in the soil have already reached a certain level. Permissible additional loads aim at avoiding or reducing further accumulations of pollutants in the soil if precautionary values have already been exceeded. These are critical input rates of heavy metals in the approval procedure of individual plants. They assume an acceptable increase in concentrations in the soil if precautionary values have already been exceeded by the existing pollution. The permissible additional loads are therefore only of limited precautionary character in the sense of a sustainable avoidance of risks 
Table 1 Assessment values for heavy metal fluxes or concentrations for the protection of ecosystems and human health

\begin{tabular}{|c|c|c|c|c|c|c|}
\hline \multirow[t]{3}{*}{ Metal } & $\begin{array}{l}\text { TA Luft } \\
\text { Tab. } 6^{\mathrm{a}}\end{array}$ & $\begin{array}{l}\text { TA Luft } \\
\text { Tab. } 8^{b}\end{array}$ & BBodSchVc & 39th BImSchVe,f & EU-Directive 2004/107/EG ${ }^{e}$ & EU-Directive 2008/50/EG ${ }^{\mathrm{e}}$ \\
\hline & \multicolumn{3}{|c|}{ Emitter-related } & \multicolumn{3}{|l|}{ General load } \\
\hline & \multicolumn{6}{|c|}{$\left[g_{h a}^{-1} a^{-1}\right]$} \\
\hline \multirow[t]{2}{*}{ Mercury (Hg) } & 4 & Field: 110 & 1.5 & & & \\
\hline & & Grassland: 11 & & & & \\
\hline \multirow[t]{5}{*}{ Cadmium (Cd) } & 7 & Field: 9 & 6 & Housing settlement: 4.4 & Housing settlement: 4.4 & \\
\hline & & Grassland: 117 & & Coniferous forest: 7 & Coniferous forest: 7 & \\
\hline & & & & Deciduous forest: 4 & Deciduous forest: 4 & \\
\hline & & & & Grassland: 2.5 & Grassland: 2.5 & \\
\hline & & & & Field: 2.5 & Field: 2.5 & \\
\hline \multirow[t]{5}{*}{ Lead $(\mathrm{Pb})$} & 365 & Field: 675 & 400 & Housing settlement: 435 & & Housing settlement: 435 \\
\hline & & Grassland: 6935 & & Coniferous forest: 716 & & Coniferous forest: 716 \\
\hline & & & & Deciduous forest: 420 & & Deciduous forest: 420 \\
\hline & & & & Grassland: 250 & & Grassland: 250 \\
\hline & & & & Field: 250 & & Field: 250 \\
\hline \multirow[t]{5}{*}{ Arsenic (As) } & 15 & Field: 4271 & & Housing settlement: 5.2 & Housing settlement: 5.2 & \\
\hline & & Grassland: 219 & & Coniferous forest: 6 & Coniferous forest: 6 & \\
\hline & & & & Deciduous forest: 4 & Deciduous forest: 4 & \\
\hline & & & & Grassland: 2.2 & Grassland: 2.2 & \\
\hline & & & & Field: 2.2 & Field: 2.2 & \\
\hline \multirow[t]{5}{*}{ Nickel (Ni) } & 55 & & 100 & Housing settlement: 17.4 & Housing settlement: 17.4 & \\
\hline & & & & Coniferous forest: 28 & Coniferous forest: 28 & \\
\hline & & & & Deciduous forest: 17 & Deciduous forest: 17 & \\
\hline & & & & Grassland: 10 & Grassland: 10 & \\
\hline & & & & Field: 10 & Field: 10 & \\
\hline Copper (Cu) & & & 360 & & & \\
\hline $\operatorname{Zinc}(\mathrm{Zn})$ & & & 1200 & & & \\
\hline Chrome $(\mathrm{Cr})$ & & & 300 & & & \\
\hline Thallium (TI) & 7 & 26 & & & & \\
\hline \multicolumn{7}{|c|}{ a TA Luft = Technical Instructions for Air pollution control (deposition values to protect human health) } \\
\hline \multicolumn{7}{|c|}{ b TA Luft = Technical Instructions for Air pollution control (deposition values as reference points for the special case examination to protect environment) } \\
\hline \multicolumn{7}{|c|}{ ' BBodSchV = Federal Soil Protection Ordinance (permissible additional load according to $§ 11$ para. 2) } \\
\hline \multicolumn{7}{|c|}{ d 39th BImSchV $=39^{\text {th }}$ Federal Immission Control Ordinance } \\
\hline \multicolumn{7}{|c|}{ e Converted from assessment values for concentrations [4]: Tables 33 and 34) } \\
\hline
\end{tabular}

of harmful effects due to accumulation of pollutants. They are more comparable with a bagatelle or irrelevant threshold.

Finally, the Water Framework Directive [16] contains priority substances, including the heavy metals lead, cadmium, nickel and mercury. These effect concentrations are to be included in the assessment of heavy metal inputs from a variety of entry paths, even if critical deposition cannot be directly derived from them. Table 1 in conjunction with Additional file 1: Table S1.1 provides an overview of existing legally binding assessment values. The regulations and recommendations compiled in Table 1 and Additional file 1: Table S1.1 contain different categories of assessment values which differ with regard to their protective purpose, the respective level of protection and protective objective. For this reason, this study uses the overarching term "assessment value", but takes over the nomenclature of quotations from the rules and regulations. In addition, a distinction is made between precautionary assessment values and those which serve to avert danger. Precautionary assessment values indicate limits of resilience (concentrations in environmental compartments or substance flows) below which there is no concern of significant impairment of ecosystems and their functions and services to humans. They apply generally, i.e. beyond the sphere of influence of concrete facilities, projects or management measures, and they are independent of usage claims. In law, the concept of 
danger is always linked to a certain probability of the occurrence of significant, harmful changes. In principle, assessment values that serve to avert hazards permit higher pollutant concentrations or inputs than precautionary ones. As a rule, they serve to assess concrete (including planned) facilities, projects or management measures and are derived from specific uses (e.g. test values and measure values in soil protection). Table $1 \mathrm{com}$ piles the assessment values used in this study to compare them with critical loads. Due to the methodological differences in their derivation, they are only comparable to each other to a limited extent and with critical loads. The differences, some of which are clear, are due to different levels of protection, protection objectives and the relationship between effects (Additional file 1: Table S1.1).

\section{Objective}

The protection of human health and ecosystems and their functions against adverse effects from air pollutant deposition is generally ensured if heavy metal inputs are completely avoided. However, this is currently not a realistic assumption. On the basis of empirical evidence, it is assumed that protection of these objects of protection is possible if specific critical concentrations of heavy metals in environmental media are not reached for reasons of eco- and human toxicology. But only with the critical load calculations the balance between inputs and outputs can be proved. Critical loads for Germany are therefore determined below.

Critical loads for $\mathrm{Cd}, \mathrm{Pb}, \mathrm{Hg}$ have already been calculated for the entire EMEP ${ }^{2}$ region. They serve as policy advice, in particular to examine and justify whether further emission reductions are necessary. To date, they have not been designed as binding immission or deposition values. The critical loads indicate the total input rate below which adverse effects on ecosystems and human health (paths atmosphere-soil-groundwater for drinking water use and atmosphere-soil-food wheat (only for $\mathrm{Cd}$ )) can be excluded in the long term according to current knowledge. Consequently, if the critical loads are complied with, risk minimisation is achieved below the classic danger threshold, which means that the assessment values are very precautionary.

The critical load concept focuses on the budgets of substances in ecosystems. Ecosystem-specific features (soil, climate, use, etc.) are taken into account when calculating the critical load values. As a result, there is no only one "critical load", but rather a range of values that allows a comprehensive, regionalised representation of the sensitivity of ecosystems, food crops and drinking water to heavy metals.

In addition to natural and semi-natural ecosystems, agricultural land is also considered both as ecosystems and as areas where human and ecotoxicological values must be respected. Critical loads aimed at protecting ecosystems are hereinafter referred to as $\mathrm{CL}(\mathrm{M})_{\text {eco. }}$ Critical loads aimed at protecting human health, e.g. drinking water, are abbreviated $\mathrm{CL}(\mathrm{M})_{\text {drink }}$ and those aimed at protecting food for humans $\mathrm{CL}(\mathrm{M})_{\text {food }}$, where $(\mathrm{M})$ stands for heavy metal and can be replaced by the respective element symbol $(\mathrm{Cd}, \mathrm{Pb}, \mathrm{Hg}, .$.$) . The determination of$ $\mathrm{CL}(\mathrm{M})_{\text {eco }}$ is based exclusively on ecotoxicological threshold values. This means that the $\mathrm{CL}(\mathrm{M})_{\mathrm{eco}}$ are determined on the basis of effects. Experimentally determined zero effect threshold values (NOEC or $\mathrm{PNEC}^{3}$ ) are used as "critical limits" in the calculation of the $\mathrm{CL}(\mathrm{M})_{\mathrm{eco}}$. For the $\mathrm{CL}(\mathrm{M})_{\text {drink, }}$ internationally agreed critical concentrations were used in drinking water and for $\mathrm{CL}(\mathrm{Cd})_{\text {food }}$ in food wheat.

\section{Materials and methods for calculation of critical loads for heavy metals in Germany \\ Basic principles for determination of critical loads for heavy metal deposition}

In the following, an assessment of the input rates into ecosystems in the equilibrium of inputs and outputs will be carried out according to the critical loads concept. Their mapping for Germany is carried out on a scale of 1:1 million and provides an overview of the sensitivity of terrestrial ecosystems to nine heavy metals. Ecosystem integrity [17] and human health are regarded as protection goals.

By definition, critical loads for heavy metals are the highest total input rate of the metal under consideration (from atmospheric deposition, fertilisers and other anthropogenic sources) below which no long-term adverse effects on human health and on the structure and function of ecosystems are to be expected according to the current state of knowledge [18]. Critical load is calculated according to the mass balance approach assuming a chemical equilibrium in the system under consideration and a steady state at a concentration level defined by the critical limit. This is an impact-based derived limit concentration in certain ecosystem compartments below which significant adverse effects on human health as well as on defined sensitive components of ecosystems can be excluded according to the current state of knowledge.

\footnotetext{
${ }^{2}$ Co-operative programme for monitoring and evaluation of the long-range transmission of air pollutants in Europe (inefficially 'European Monitoring and Evaluation Programme' =EMEP).
}

${ }^{3} N O E C$ no observed effect concentration, $P N E C$ predicted no-effect concentration. 
Table 2 Receptor types and their area proportions according to CORINE [20] in Germany

\begin{tabular}{|c|c|c|c|c|}
\hline CORINE code & Description of the CORINE code & Area in Germany [ha] & $\begin{array}{l}\text { Surface area } \\
\text { in Germany [\%] }\end{array}$ & $\begin{array}{l}\text { Proportion } \\
\text { of total receptors } \\
\text { [\%] }\end{array}$ \\
\hline 211 & Arable land & 13410853 & 37.53 & 47.9 \\
\hline 231 & Meadows and pastures & 4266058 & 11.94 & 15.2 \\
\hline 311 & Deciduous forests & 2359267 & 6.60 & 8.4 \\
\hline 312 & Coniferous forests & 5436535 & 15.21 & 19.4 \\
\hline 313 & Mixed forests & 2302725 & 6.44 & 8.3 \\
\hline 321 & Natural grassland & 99061 & 0.28 & 0.4 \\
\hline 322 & Heaths and moor heaths & 35776 & 0.10 & 0.1 \\
\hline 411 & Marshes & 19755 & 0.06 & 0.1 \\
\hline 412 & Peat bogs & 58577 & 0.16 & 0.2 \\
\hline Sum of receptor surfaces & & 27988609 & 78.32 & 100.0 \\
\hline
\end{tabular}

Cadmium has been identified as an important pollutant in relation to the maintenance of food quality for the protection of human health. With this metal, uptake from the soil into the vegetation is comparatively high, so that accumulations in the soil entail the potential danger of health effects via plant food. Wheat was selected as the indicator plant. Wheat grain accounts for a significant proportion of food in Germany (as in Europe) and its cultivation accounts for a large proportion of agricultural land in Germany (and other European countries) [19]. Critical loads for the protection of drinking water are mapped for all ecosystem types. Critical loads are therefore determined below for three objects of protection:

1. $\mathrm{CL}(\mathrm{M})_{\text {eco }}$ : critical load for a metal (M stands for $\mathrm{Hg}$, $\mathrm{Cd}, \mathrm{Pb}, \mathrm{Cu}, \mathrm{Zn}, \mathrm{Ni}, \mathrm{As}, \mathrm{Cr}, \mathrm{Zn}$ ) to protect the sensitive biota of the ecosystem;

2. $\mathrm{CL}(\mathrm{M})_{\text {drink: }}$ : critical load for a metal ( $\mathrm{M}$ stands for $\mathrm{Hg}$, $\mathrm{Cd}, \mathrm{Pb}, \mathrm{Cu}, \mathrm{As}, \mathrm{Cr}, \mathrm{Zn}$ ) for Protection of drinking water for human beings;

3. $\mathrm{CL}(\mathrm{Cd})_{\text {food }}$ : critical load for cadmium for the protection of arable crops (here: wheat-producing as a food for human beings.

\section{Data base}

For the critical load calculation, the necessary data is spatially linked with the geographical information system ArcView and transferred to a database. Both original data such as precipitation and derived data such as values for the organic matter content $(\mathrm{OM})$ and $\mathrm{pH}$ values derived from the soil overview map BÜK1000N are used. The storage, evaluation and presentation of the data are done in polygons, which result from the intersection of the input data.

\section{Biotope type and land use mapping}

The spatial distribution of the investigated receptors in Germany is taken from the CORINE Land Cover 2006 [20]. Critical loads are calculated for natural and semi-natural ecosystems and for agricultural land (arable and intensive grassland). Settlement areas, water areas, etc. (21.8\% of the area of Germany) are not included as receptor areas. The following legend units of the [20] are therefore regarded as receptor surfaces (Table 2).

\section{Soil map}

The land use-differentiated soil overview map of the Federal Republic of Germany on a scale of 1:1,000,000 (BÜK1000N Version 2.3.1; BGR [21]) shows the spatial distribution of soil forms, summarised in soil associations (=soil units). In contrast to the BÜK 1000 [22] with its 71 pedological legend units, the polygons of the BÜK1000N are significantly characterised by soil and land use information. Thus, 66 legend units are combined with land use arable land, 56 with grassland and 63 legend units with forest. Taking into account the differentiation achieved by regionalisation (European climate zones), a total of 675 legend descriptions and guiding soil profiles are available for these three main uses. For each soil profile, the humus form of the organic layers, the (fine) soil types of the mineral horizons, the horizon sequence with thickness data and for each horizon the soil systematic unit, the total nitrogen content and the carbonate class, the $\mathrm{pH}$ level, the bulk density, the storage density, the field capacities, the total pore volume, the humus class and the concentrations of exchangeable cations are indicated.

\section{Long-term mean of temperature and precipitation}

The following grid databases have been made available by the German Weather Service in Offenbach (DWD), Climate and Environment Department: 
4. Average monthly air temperature for the months January-December from the period 1981-2010 [23] and

5. Average monthly rainfall for the months JanuaryDecember from the period 1981-2010 [24].

The data are available as ASCII file and results in a matrix of $650 \times 880$ points. Each of these points embodies the value of a $1 \times 1 \mathrm{~km}^{2}$ cell. The limits of the data field range from right value $3,280,000$ to right value $3,930,000$ and from high value $5,230,000$ to high value $6,110,000$ of the Gauss-Krüger coordinate system.

\section{Average annual leachate rate}

The data on the land-use-differentiated mean annual leachate rate from soil for the climate period 1981-2010 were made available digitally by the BGR in October 2014 [25]. The regional allocation of land use classes is based on CORINE Land Cover 2006 [20]. The data set describes the spatial distribution of the leachate rates with a grid resolution of $1 \times 1 \mathrm{~km}^{2}$ on the geometric reference base of the ATKIS-DLM 1000.

\section{Derivation and regionalisation of ecological receptors}

While the data basis for the soil-specific parameters, which are included in the simple mass balance, with the BÜK1000N [21], in particular with the use type-specific leading soil profiles, is sufficiently accurate for determining the sensitivity of ecosystems, the rough biotope type and land use types of the CORINE Land Cover 2006 [20] are not sufficient for all vegetation-specific parameters for the mass balance. For this reason, this study assigned typical semi-natural vegetation units and crop rotations to the leading soil profiles of the BÜK1000N. The usage differentiation of the BÜK1000N is, however, also too rough for this. For example, guide soil profiles are only available for arable land, grassland and forests. The allocation of the vegetation units to guide soil profiles was therefore carried out at the following levels:

6. BÜK guide soil profile "Grassland" differentiated according to meadows and pastures (CORINE class 231), natural grassland (CORINE class 321), heaths and moorland (CORINE class 322), swamps (CORINE class 411) and peat bogs (412),

7. BÜK guide soil profile "forests" differentiated according to deciduous forest (CORINE class 311), coniferous forest (CORINE class 312) and mixed forest (CORINE class 313)

8. BÜK guide soil profile "Arable land" undifferentiated for CORINE class 211.

The assignment of the semi-natural vegetation units is based on the database of the BERN model [26, 27]. For the intensively used vegetation complexes, the currently typical vegetation units were assigned to the combinations of BÜK1000N guide soil profile and CORINE unit, i.e. e.g. for the "coniferous forest" predominantly forest associations, for the "meadows and pastures" predominantly meadow associations. For the CORINE classes deciduous forest (311), natural grassland (CORINE class 321), heaths and moor heaths (CORINE class 322), marshes (CORINE class 411) and peat bogs (412), the semi-natural or near-natural plant community was assigned in each case, which is to be expected as typical on the basis of the site conditions according to the information of the BÜK1000N on the leading soil profile and the climate area. 226 plant communities were assigned to the 210 guide soil profiles, each with 7 CORINE classes. For forests in particular, this means that it is now possible to take account of a site-typical mixture of tree species, so that a more sensitive mixed tree species may also determine the critical limit instead of the less sensitive dominant main tree species, as has been customary to date. The potential yield can also be more finely differentiated for mixtures of species such as those found in deciduous and mixed forests, but also in open country.

The CORINE class arable land (2.1.1) was assigned arable crop rotations that correspond to good professional practice according to the soil shape. The distribution of cultivated areas was checked against the data of the Federal Statistical Office [28] for the years 2007-2013 (mean value for federal states) and adjusted accordingly. Additional file 1: Table S1.2 contains the assumed crop rotations according to good professional practice on the soil units of BÜK1000 as well as the typical area distribution of crop rotation members assumed for the calculation of critical loads.

\section{Methodological approach of the critical load calculation}

The methodological approach for the calculation of critical loads for heavy metals in this study follows the recommendations in the manual of the ICP Modeling and Mapping ([18, 29, 30], Chapter V.5). All relevant fluxes into or from a certain soil layer, in which the essential substance conversions occur or in which the receptors have their distribution focus and which is therefore relevant for the effects in the system, are compared. The consideration of heavy metal fluxes, reserves and concentrations refers to mobile or potentially mobilisable metals, only they are relevant for the consideration of substance fluxes.

The mass balance equation includes as output paths from the terrestrial ecosystem the uptake into the biomass with subsequent harvest and the output with the leachate flow as follows: 


$$
\mathrm{CL}(\mathrm{M})=\mathrm{M}_{u}+\mathrm{M}_{\mathrm{le}(\text { crit })},
$$

with $\mathrm{CL}(\mathrm{M})$ as critical load of the metal $\mathrm{M}\left[\mathrm{g} \mathrm{ha}^{-1} \mathrm{a}^{-1}\right]$, $M_{u}$ as net uptake of the metal $M$ into harvestable plant parts $\left[\mathrm{g} \mathrm{ha}^{-1} \mathrm{a}^{-1}\right], \mathrm{M}_{\text {le(crit) }}$ the tolerable (critical) leaching of the metal $\mathrm{M}$ from the considered soil layer with exclusive consideration of vertical rivers (leachate) $\left[\mathrm{g} \mathrm{ha}^{-1}\right.$ $\mathrm{a}^{-1}$.

The inclusion of further terms is in accordance with the recommendations of the Expert Panel for Heavy Metals to the ICP Modeling and Mapping [31, 19]. There have been no changes to this approach since 2004 [19].

\section{Calculations}

\section{Removal of heavy metals}

The removal rate of heavy metals with the harvest of biomass results from the yield of the biomass to be harvested, multiplied by the substance content as follows:

$$
\mathrm{M}_{u}=[\mathrm{M}]_{\mathrm{ha}} \cdot E,
$$

with $\mathrm{M}_{u}$ as heavy metal removal rate $\left[\mathrm{g} \mathrm{ha}^{-1} \mathrm{a}^{-1}\right],[\mathrm{M}]_{\mathrm{ha}}$ as metal content in the dry matter of the harvest $\left[\mathrm{mg} \mathrm{kg}^{-1}\right]$, and $E$ as the dry matter yield of the crop $\left[\mathrm{kg} \mathrm{ha}^{-1} \mathrm{a}^{-1}\right]$.

By definition, critical loads are not intended to cause long-term adverse effects on human health or on the structure and function of ecosystems. Thus, they should not reflect the status quo in terms of farming methods and the resulting cultivation conditions and yields, but should follow long-term principles of sustainable agriculture and forestry. Therefore, the critical load approach is based on the following assumptions about the management of receptor areas:

\section{Forests}

In the long term, it can be assumed that the conversion to near-natural forest management, which has already begun nationwide, in combination with the trend towards a reduction in nitrogen inputs, will regulate the potential timber yield expectation and the material content to a sustainable and stable equilibrium. For this reason, conservative assumptions were made for earnings and salary estimates, which are derived from measurement data at more or less unpolluted locations.

2. Acre

The field yields were derived from current harvest statistics. In contrast to forest management, there are no discernible trends towards extensification in arable farming in Germany (apart from organic farming, whose share of land has remained stable at a low level in recent years). Even after its amendment, the Fertiliser Ordinance still tolerates a high level of excess fertilisation with nitrogen. With regard to crop rotations, i.e. for the cultivation conditions of the individual crop types, it is assumed, however, that the rules of good professional practice (in particular phytosanitary favourable, nutrient-effective and soil-preserving crop rotations) are applied, even if at present in particular the cultivation conditions, but also the use of fertilisers and thus the yields in agriculture are predominantly made dependent on support programmes and on the market. This must not be assumed in the following, since on the one hand the critical loads are to apply in the long term, but on the other hand cultivation conditions in the longer term should not be predicted on the basis of today's market conditions. For the future, it can be assumed that the cultivation structure will correspond to good professional practice in the long term.

3. Open woodless country

A distinction was made between unused openland ecosystem types (peat bogs, swamps, moor heaths) and those that are regularly used (natural grassland, dry heaths, salt marshes). The estimation of the dry matter yield in openland habitats in use assumes that a minimum use or maintenance use is necessary to maintain the stock. However, this necessary minimum use also depends on the biomass production potential of the respective location.

\section{Heavy metal contents in the biomass}

The annual heavy metal removal $\left(\mathrm{M}_{u}\right)$ for used forests results from the estimated biomass removal by the annual increase in solid wood and bark of the main and secondary tree species of the current stocking at the site, multiplied by the average content of heavy metals in solid wood and bark (Table 3). These contents can be regarded as sustainably compatible and thus acceptable in the long term, since only measured values from areas that are not specifically contaminated were evaluated for this purpose. For the compilation of the heavy metal contents by Jacobson et al. [32], data from 45 sites in Germany were evaluated. Reinds et al. [33] considered values from three sites in Europe.

$\mathrm{M}_{u}$ for grassland biotopes and arable crops used results from the growth rate of above-ground green matter in the year $\left[\mathrm{tha}^{-1} \mathrm{a}^{-1}\right]$ and the heavy metal contents in the harvest mass (from investigations without specific load) according to Table 4.

\section{Assessment of the plant physiological yield potential of biomass to be harvested}

The export of biomass must be estimated from the biomass productivity depending on the yield potential of the site, taking into account the plant physiologically possible 
Table 3 Heavy metal contents ( $\mathrm{mg} \mathrm{kg}^{-1}$ dry matter) in solid wood with bark of main tree species $(n=45)$

\begin{tabular}{|c|c|c|c|c|c|c|c|c|}
\hline \multirow[t]{2}{*}{ Tree species } & \multicolumn{8}{|c|}{ Heavy metal content $[\mathrm{M}]_{\mathrm{ha}}\left(\mathrm{mg} \mathrm{kg}^{-1}\right.$ dry matter) } \\
\hline & $\overline{\mathrm{Pb}^{\mathrm{a}}}$ & $\mathrm{Cd}^{\mathrm{a}}$ & $\mathrm{Hg}^{\mathrm{a}}$ & $\mathrm{Cu}^{\mathrm{a}}$ & $\mathrm{Ni}^{\mathrm{a}}$ & $Z^{a}$ & $A s^{b}$ & $\mathrm{Cr}^{\mathrm{a}}$ \\
\hline Oak & 2.97 & 0.13 & 0.02 & 2.19 & 1.58 & 5.27 & 0.02 & 0.74 \\
\hline Beech & 1.52 & 0.15 & 0.02 & 1.77 & 1.28 & 10.53 & 0.02 & 0.54 \\
\hline Spruce & 1.29 & 0.36 & 0.02 & 1.67 & 1.18 & 31.2 & 0.01 & 0.42 \\
\hline Pine & 1.75 & 1.31 & 0.02 & 1.35 & 1.85 & 25.24 & 0.01 & 0.35 \\
\hline All others on average & 1.81 & 0.29 & 0.02 & 1.91 & 1.48 & 11.20 & 0.015 & 0.53 \\
\hline
\end{tabular}

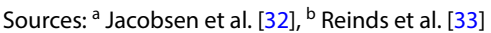

Table 4 Heavy metal contents ( $\mathrm{mg} \mathrm{kg}^{-1}$ dry matter) of arable crops and grassland

\begin{tabular}{|c|c|c|c|c|c|c|c|c|c|}
\hline \multirow[t]{2}{*}{ Plant species } & \multirow[t]{2}{*}{$\mathbf{N}$} & \multicolumn{8}{|c|}{ Heavy metal content $[\mathrm{M}]_{\text {ha }}$ (mg kg ${ }^{-1}$ dry matter) } \\
\hline & & $\mathrm{Pb}$ & $C d$ & $\mathrm{Hg}$ & $\mathrm{Cu}$ & $\mathrm{Ni}$ & $\mathrm{Zn}$ & As & $\mathrm{Cr}$ \\
\hline Winter wheat ${ }^{a}$ & 24 & 0.03 & 0.03 & 0.005 & 4.6 & 0.23 & 20 & 0.035 & 0.48 \\
\hline Rye & 23 & 0.07 & 0.02 & 0.005 & 4.6 & 0.44 & 26 & 0.035 & 0.25 \\
\hline Winter barley ${ }^{b}$ & 30 & 0.1 & 0.02 & 0.01 & 3.6 & 0.23 & 25 & 0.035 & 0.27 \\
\hline Rapeseed $^{c}$ & 18 & 0.1 & 0.08 & 0.003 & 3.8 & 0.81 & 39 & 0.035 & 1.7 \\
\hline Potatoes & 32 & 0.04 & 0.09 & 0.001 & 4.6 & 0.23 & 14 & 0.035 & 0.17 \\
\hline Sugar beet & 30 & 0.2 & 0.08 & 0.01 & 3.9 & 0.8 & 12 & 0.035 & 0.47 \\
\hline Silage maize $e^{e}$ & 24 & 0.2 & 0.04 & 0.02 & 3.5 & 0.58 & 19 & 0.035 & 0.73 \\
\hline Grass and grassland plants ${ }^{d}$ & 160 & 0.99 & 0.13 & 0.03 & 6.2 & 0.91 & 49.5 & 0.1 & 0.395 \\
\hline
\end{tabular}

Source: Knappe et al. [54]

a The share of the area under spring wheat is negligibly small compared to the area under winter wheat [28] and is therefore not considered in crop rotation

b The share of the area under spring barley is negligibly small compared to the area under winter barley [28] and is therefore not considered in crop rotation

c The proportion of sunflower area cultivated is negligibly small compared to the area under rape [28] and is therefore not considered in crop rotation

$d$ The share of the area under legumes is negligibly low compared to the area under grassland [28] and is therefore not considered in crop rotation

e Silage maize is defined here as energy maize, green maize and feed silage maize

biomass growth. The basis for the site type-specific estimation of the potential wood yield in forests is provided by yield tables of the growth of tree species at non-influenced sites, in particular from as old measurements as possible. Over 100 years, the average annual increase for yield class I and the worst yield class of the tree species is determined from the yield tables (Table 5). The fixed measurement increments (DGZ 100) determined in this way are converted into weight measurement increments with the aid of the tree species-specific wood and bark density [19].

The estimation of the dry matter yield in the seminatural open land receptor areas as well as for cultivated meadows and pastures (Table 6) assumes that a use or maintenance use is carried out.

The crop yields from intensive agriculture (Table 7) are taken from the data of the Federal Statistical Office [28] for the years 2007-2013 (mean value). The lower range limits were taken from the data from the federal state with the lowest yields, and the upper range limit also corresponds to the average of the years $2007-2013$ of the federal state with the highest yields of this type of fruit.

The biomass yield to be harvested depends on the yield potential of the respective location. Based on the sitespecific yield potential (soil fertility), a potential yield can be interpolated within the specified yield ranges.

\section{Soil-specific yield potential}

The method described below serves to concretise a discrete soil-typical yield value within the vegetation typespecific yield range (Tables 8,9 ), taking into account the different soil characteristics. First of all, the best possible assessment of soil fertility as a function of the soil types of the horizons of the leading soil profiles of the BÜK1000N [21] has to be esteemed (Additional file 1: Table S1.3). The respective model for that was developed by Schlutow et al. [27]. Various soil properties were assessed as very unfavourable (score 1) to very favourable (score 5) in terms of yield formation. These values refer to the horizons of the guide soil profiles from the 
Table 5 Range of yield potential of main and secondary tree species

\begin{tabular}{|c|c|c|c|c|c|}
\hline \multirow[t]{3}{*}{ Tree species } & \multicolumn{4}{|c|}{ Range of the average annual growth rates after 100 years [DGZ 100] } & \multirow[t]{3}{*}{ Yield board from } \\
\hline & \multicolumn{2}{|c|}{$\begin{array}{l}\text { Yield potential the best yield class I } \\
\text { for trunk wood with bark } \\
E_{\max (\text { Phyto) }}\end{array}$} & \multicolumn{2}{|c|}{$\begin{array}{l}\text { Yield potential the worst yield class for trunk } \\
\text { wood with bark } \\
E_{\min (\text { Phyto) }}\end{array}$} & \\
\hline & {$\left[\mathrm{m}^{3} \mathrm{ha}^{-1} \mathrm{a}^{-1}\right]$} & {$\left[\mathrm{m}^{3} \mathrm{ha}^{-1} \mathrm{a}^{-1}\right]$} & {$\left[\mathrm{m}^{3} \mathrm{ha}^{-1} \mathrm{a}^{-1}\right]$} & {$\left[\mathrm{m}^{3} \mathrm{ha}^{-1} \mathrm{a}^{-1}\right]$} & \\
\hline Scots pine & 7.8 & 3.1 & 2.0 & 0.8 & Wiedemann $[67]^{a}$ \\
\hline Norway spruce & 12.0 & 4.9 & 7.5 & 3.2 & Wiedemann $[68]^{a}$ \\
\hline White fir & & 3.5 & & 3 & Schober $[69]^{a}$ \\
\hline European larch & & 2.5 & & 2 & Schober [69] ${ }^{a}$ \\
\hline Beech & 7.8 & 4.9 & 3.7 & 2.4 & Schober [69] ${ }^{\mathrm{a}}$ \\
\hline Common and sessile oak & 6.7 & 4.0 & 2.1 & 1.4 & Mitscherlich [70] \\
\hline Black alder & 8.0 & 4.3 & 4.5 & 2.5 & Mitscherlich [70] \\
\hline Birch, all species & 4.9 & 2.8 & 3.6 & 2.1 & Schwappach [71] \\
\hline Willows, all species & 5.0 & 2.3 & 3.4 & 1.6 & Schober [72] \\
\hline Ash & 6.2 & 3.7 & 4.1 & 2.5 & Wimmenauer [73] \\
\hline Mountain ash & & 2.1 & & 1.6 & Erteld [74] \\
\hline Lime tree. all species & 8.8 & 5.2 & 5.0 & 3.0 & Böckmann [75] \\
\hline Maple, all species & & 3.5 & & 2.5 & Schober [76] \\
\hline Poplars, aspen & 13.2 & 4.5 & 3.0 & 1.1 & Knapp [77] \\
\hline Hornbeam & & 5.6 & & 2.5 & Schober [76] \\
\hline
\end{tabular}

a In Schober [72]

Table 6 Yield potentials of the different vegetation types of the forest-free near-natural/semi-natural ecosystems

Vegetation type

\begin{tabular}{lll} 
& \multicolumn{1}{l}{$\mathbf{u s e}\left[\mathbf{t ~ h a} \mathbf{~}^{\mathbf{1}} \mathbf{a}^{\mathbf{- 1}}\right]$} \\
\cline { 2 - 3 } & $\mathbf{E}_{\mathbf{m a x}(\text { Phyto) }}$ & $\mathbf{E}_{\mathbf{m i n} \text { (Phyto) }}$ \\
\hline Nutrient-poor grassland & 1.5 & 0.65 \\
Heathen & 1.4 & 0.8 \\
Dry lime turf & 1.7 & 0.11 \\
Wet and wet meadows & 2.5 & 0.1 \\
Flood meadows and floodplain meadows & 1.6 & 0.8 \\
Fresh meadows/fresh pastures & 1.5 & 0.65
\end{tabular}

Sources: Bobbink and Hettelingh [78]. Bohner et al. [79]. Bolte [80]. Brenner et al. [81]. Briemle et al. [82]. Brünner and Schöllhorn [83]. Dierschke and Briemle [84]. Elsäßer [85]. Keienburg and Prüter [86]. Klapp [87]. Luthardt et al. [53]. Petersen [88]. Quade [89]. Ruhr-Stickstoff-Aktiengesellschaft [90]. Stein-Bachinger et al. [91]. Tischew [92]
BÜK-1000N database. In order to check the yield potential the map of the "Arable yield potential of soils in Germany" [34] based on the "Soil Quality Rating" (SQR) [35] was used. A complete adoption of this map was not productive, as this method was developed only for arable land and not also for forests, natural open land, meadows and pastures. The comparison of the scores, however, led to changes in the valuation with regard to the groundwater and evapotranspiration influence and with regard to rootability in Additional file 1: Table S1.3.

\section{Data compilation}

The individual criteria described here to indicate the yield potential cannot be equally weighted in the estimation of the yield potential, because individual criteria have a greater influence on plant growth than others and sometimes affect several different physiological processes.

Table 7 Yield ranges $E_{\min (P h y t o)}-E_{\max (\text { Phyto) }}$ throughout Germany, averaged over the years 2007-2013

\begin{tabular}{|c|c|c|c|c|c|c|c|c|c|c|c|c|c|c|c|}
\hline \multicolumn{16}{|c|}{ Yields in t dry matter per year $\mathrm{E}_{\min (\text { Phyto) }}\left(=" \min ^{\prime \prime)} \mathrm{E}_{\max (\text { Phyto) }}(=" \max\right.$ ") } \\
\hline \multicolumn{2}{|c|}{ Wheat } & \multicolumn{2}{|l|}{ Rye } & \multicolumn{2}{|c|}{ Barley } & \multicolumn{2}{|c|}{ Roughage } & \multicolumn{2}{|c|}{ Beta beet } & \multicolumn{2}{|c|}{ Potatoes } & \multicolumn{2}{|c|}{ Rape seed } & \multicolumn{2}{|c|}{ Silage maize } \\
\hline Min & Max & Min & Max & Min & Max & Min & Max & Min & Max & Min & Max & Min & Max & Min & Max \\
\hline 6.2 & 8.8 & 4.2 & 6.5 & 5.3 & 7.6 & 5.3 & 8.6 & 58 & 72 & 35 & 48 & 3.4 & 3.9 & 34 & 51 \\
\hline
\end{tabular}

Source: Federal Statistical Office [28] 


\begin{tabular}{|c|c|}
\hline Individual parameter & $\begin{array}{l}\text { Synthesis } \\
\text { to the main } \\
\text { influencing factors }\end{array}$ \\
\hline $\begin{array}{l}\text { Usable field capacity } \\
\text { Porosity with dead water (tendency to waterlog- } \\
\text { ging) risk of dehydration } \\
\text { Influence of groundwater and backwater }\end{array}$ & Soil water balance \\
\hline $\begin{array}{l}\text { Cation exchange capacity } \\
\text { Usable field capacity } \\
\text { Humus content }\end{array}$ & Nutrient balance \\
\hline $\begin{array}{l}\text { Thoroughness } \\
\text { Rootability } \\
\text { Hardening tendency }\end{array}$ & Soil structure \\
\hline
\end{tabular}

For this reason, the individual parameters in Additional file 1: Table S1.3 have been combined in accordance with Table 8 to form the main factors influencing yield formation and the mean values of the classes have been calculated. The mean value was then determined from the 3 main influencing factors. It corresponds to the yield potential of the soil horizon $\mathrm{EP}_{\text {(geo-hor) }}$ in the last column of Additional file 1: Table S1.3.

The relative yield potential of the soil $\mathrm{EP}_{\text {(geo-hor) }}$ was now assigned for each horizon of the soil profile of the
BÜK1000N based on the data of the soil type and then averaged to the rooting depth (following section) using a depth-weighted average. This corresponds to the yield potential of the reference profile $\mathrm{EP}_{\text {(geo-prof). }}$

\section{Determination of the rooted soil depth as a function of vegetation- and soil-specific root penetration potentials}

The vegetation-specific root penetration depth of the dominant and characteristic species could be estimated on the basis of the assigned plant community (Sect. 3.3). This was the prerequisite for averaging the horizontal data of the critical load-relevant parameters from the guide soil profiles. On the other hand, the depth actually rooted by plants also depends on the rootable depth of the soil. Starting from the potential length of the main root habit $(=80 \%$ of the total root mass) of the characteristic main tree species or the characteristic type of herb layer [36], the potential root penetration depths for the main stands shown in Table 9 can be given. These potential root lengths are limited by the upper edge of the terrestrial subsoil horizon $(\mathrm{C}$ horizons) for most vegetation types (except for the pioneer tree species mountain pine, aspen and birch), by the upper edge of the oxygen-free (reduced) groundwater or backwater horizon $(\mathrm{Gr} / \mathrm{Sr}$ horizons) for wet-avoiding tree species, or by the upper edge of the reduced-gas horizon

Table 9 Length of the main root mass according to Köstler et al. [36] and horizons cutting off the root mass that cannot be rooted through (from Nagel et al. [19], supplemented and updated)

\begin{tabular}{|c|c|c|}
\hline Vegetation type/main tree species & Potential main root length $[\mathrm{cm}]$ & $\begin{array}{l}\text { Horizons that cannot be rooted } \\
\text { through (according to soil mapping } \\
\text { instructions KA 5. p. 83ff) }\end{array}$ \\
\hline Arable crops & 40 & C C;P;Gr;Y;F;Sr;Sd;Sg \\
\hline Natural grassland & 40 & $\mathrm{C} ; \mathrm{P} ; \mathrm{Gr} ; Y ; F ; G o ; S$ \\
\hline Heaths and moor heaths & 20 & $C ; P ; G r ; Y ; F ; S r ; S$ \\
\hline Marshes & 110 & $C_{;} P ; Y ; F r$ \\
\hline Peat bogs & 90 & $C ; P ; Y ; F r$ \\
\hline Meadows and pastures & 60 & C C;P;Gr;Y;F;Sr;Sd;Sg \\
\hline Scots pine & 180 & $\mathrm{C} ; \mathrm{P} ; \mathrm{Gr} ; \mathrm{Y} ; \mathrm{F} ; \mathrm{Sr} ; \mathrm{Sd} ; \mathrm{Sg}$ \\
\hline Spruce & 80 & $\mathrm{C} ; \mathrm{P} ; \mathrm{Gr} ; \mathrm{Y} ; \mathrm{F} ; \mathrm{Sr} ; \mathrm{Sd} ; \mathrm{Sg}$ \\
\hline Copper beech & 80 & $\mathrm{C} ; \mathrm{P} ; \mathrm{Gr} ; \mathrm{Y} ; \mathrm{F} ; \mathrm{Go} ; \mathrm{Sr} ; \mathrm{Sd} ; \mathrm{Sg}$ \\
\hline Alder, ash tree & 80 & $\mathrm{C} ; \mathrm{P} ; \mathrm{Gr} ; \mathrm{Y} ; \mathrm{F} ; \mathrm{Sr} ; \mathrm{Sd} ; \mathrm{Sg}$ \\
\hline Oak (all species) & 180 & $\mathrm{C} ; \mathrm{P} ; \mathrm{Gr} ; \mathrm{Y} ; \mathrm{F} ; \mathrm{Sr} ; \mathrm{Sd} ; \mathrm{Sg}$ \\
\hline Larch, Douglas fir & 100 & $C ; P ; G r ; Y ; F ; G o ; S$ \\
\hline Maple (all species) & 80 & $C ; P ; G r ; Y ; F ; G o ; S$ \\
\hline Poplars, aspen & 120 & \\
\hline Mountain pine & 180 & \\
\hline Black pine & 180 & $\mathrm{C} ; \mathrm{P} ; \mathrm{Gr} ; \mathrm{Y} ; \mathrm{F} ; \mathrm{Sr} ; \mathrm{Sd} ; \mathrm{Sg}$ \\
\hline Birch & 100 & \\
\hline Lime tree (all species), hornbeam, Robinia & 100 & $\mathrm{C} ; \mathrm{P} ; \mathrm{Gr} ; Y ; F ; G O ; S$ \\
\hline Willows and elms (all species) & 60 & $\mathrm{C} ; \mathrm{P} ; \mathrm{Gr} ; \mathrm{Y} ; \mathrm{F} ; \mathrm{Sr} ; \mathrm{Sd} ; \mathrm{Sg}$ \\
\hline
\end{tabular}


(Y horizons) for all vegetation types. This means that the vegetation-typical potential root length is cut off by the site-specific soil profile in cases where the potential root length is greater than the upper depth of the uppermost non-rootable horizon (=physiological thoroughness).

The thickness of each soil horizons was taken from BÜK1000N. The soil-specific yield potential of each horizon $\mathrm{EP}_{\text {geo }}$ was then averaged over all rooted horizons, taking into account the respective horizon thickness. The result is then corrected as a function of climate parameters in the manner explained below.

\section{Determination of climate-specific yield potentials}

So far, only soil and vegetation type-specific parameters have been included in the determination of yield potentials. The length of the vegetation period is a highly significant climate-ecological influencing factor. The longer the vegetation period in the year (number of days in the year with an average air temperature of $\geq 10{ }^{\circ} \mathrm{C}$ ), the greater the net primary production. Good to very good growth rates are promoted by vegetation periods ranging from 100 days (medium montane sites) to 200 days (planar lowland sites), while in high montane and alpine regions (60-100 days) net primary production falls significantly below the soilspecific yield potential. Therefore, the soil-specific yield potential was related to the vegetation period as follows:

$$
\mathrm{EP}_{\text {(climate corr) }}=\mathrm{EP}_{(\text {geo-prof) }} \cdot\left(1+\frac{\mathrm{VZ}-165}{200-100}\right),
$$

where $\mathrm{EP}_{(\text {(klima-korr) }}$ is the climate-adjusted yield potential; $\mathrm{EP}_{\text {(geo-prof) }}$, the soil-specific yield potential of the rooted soil profile (between 1 and 5); VZ, the duration of vegetation (long-term average number of days per year with an average air temperature of $\geq 10{ }^{\circ} \mathrm{C}$ ), where 165 days is the mean value in Germany, 100-200 days is the span in Germany.

\section{Calculation of the biomass yield}

The difference between the minimum and maximum yields according to the yield tables (Tables 7, 8) was interpolated according to the relative yield potential $\mathrm{EP}_{(\text {klima-korr) }}$. The yield was thus as follows, taking into account the vegetation-specific yield ranges and the site-specific relative yield potential:
Table 10 Seepage water rates used for the calculation of the heavy metal leaching with the seepage water for the various protective goods

\begin{tabular}{|c|c|c|c|}
\hline \multirow[t]{2}{*}{ M } & Drinking water & Ecosystems & Food (wheat) \\
\hline & \multicolumn{3}{|c|}{ Seepage water rate used } \\
\hline $\mathrm{Pb}$ & $Q_{\text {le(z) }}$ & $Q_{\text {le(z) }}$ & \\
\hline $\mathrm{Cd}$ & $Q_{\mathrm{le}(z)}$ & $Q_{\text {le(z) }}$ & $Q_{\text {le(z) }}$ \\
\hline $\mathrm{Hg}$ & $Q_{\text {le(z) }}$ & $Q_{l e(z)}$ & \\
\hline ace & $Q_{\text {le(z) }}$ & $Q_{\text {le(z) }}$ & \\
\hline $\mathrm{Cu}$ & $Q_{\text {le(z) }}$ & $Q_{\text {le(z) }}$ & \\
\hline $\mathrm{Ni}$ & & $Q_{\text {le(z) }}$ & \\
\hline $\mathrm{Zn}$ & & $Q_{\text {le(z) }}$ & \\
\hline $\mathrm{Cr}$ & $Q_{\text {le(z) }}$ & $Q_{l e(z)}$ & \\
\hline
\end{tabular}

the product of leachate rate $\left(Q_{\mathrm{le}}\right)$ and critical concentration of the metal in the leachate $\left([\mathrm{M}]_{\text {sdw(crit) }}\right)$. Different soil horizons and, accordingly, leachate rates in these soil horizons are relevant for the various objects of protection (Table 10). The map of the leachate rate for Germany [25] provides the basic information for determining the water leaching from the soil layer under consideration. The original BGR data set contains values smaller than or equal to 0 for approx. $3.3 \%$ of the raster cells. When the critical loads were calculated using the simple mass balance method, negative leachate rates showed implausible results. Therefore, a method was applied which is proposed in the Mapping Manual [30] p. V - 48) to correct the original seepage rates with the help of the precipitation data (long-term mean 1981-2010) of the DWD as follows: for each grid, the annual precipitation was calculated multiplied by 0.05 ( $=5 \%$ of the precipitation). Then the original leachate rate from BGR [25] in each grid is compared with $5 \%$ of precipitation. The higher value represents the new value for the leachate rate in the grid. With this method negative values could be excluded.

These corrected water flows are equal to the seepage water rates below the rooted soil layer $(z)\left(Q_{\mathrm{le}(z)}\right)$. These water flows were used unchanged in the calculation of $\mathrm{CL}(\mathrm{M})_{(\text {drink) }}$. It is assumed that the protection of groundwater against exceeding the drinking water

$$
E=E_{\min (\text { Phyto })}+\left(\left(\left(E_{\max (\text { Phyto })}-E_{\min (\text { Phyto })}\right) / 4\right)\left(\mathrm{EP}_{\text {klima-karr }}-1\right) .\right.
$$

\section{Output of heavy metals with the leaching}

The tolerable (critical) leaching of the metal $\mathrm{M}\left(\mathrm{M}_{\mathrm{le}(\mathrm{crit})}\right)$ out of the considered soil layer with exclusive consideration of vertical fluxes (leachate) $\left[\mathrm{g} \mathrm{ha}^{-1} \mathrm{a}^{-1}\right]$ results from limit values by anthropogenic pollutant inputs is guaranteed if the limit values in the leachate directly below the root zone are not exceeded. Possible interactions 
Table 11 Current internationally used guideline and limit values for the concentration of heavy metals in drinking water

\begin{tabular}{|c|c|c|c|c|c|c|c|}
\hline \multirow[t]{2}{*}{ Directive or regulation } & \multicolumn{7}{|c|}{ Reference and limit values for the concentration in drinking water $\left[\mathrm{mg} \mathrm{I}^{-1}\right]$} \\
\hline & $\mathrm{Pb}$ & Cd & $\mathrm{Hg}$ & As & $\mathrm{Cr}$ & $\mathrm{Cu}$ & $\mathrm{Zn}$ \\
\hline Drinking Water Ordinance for Germany [38] & 0.01 & 0.003 & 0.001 & 0.01 & 0.05 & 2 & - \\
\hline WHO guideline [93] & 0.01 & 0.003 & $\begin{array}{l}0.001^{\mathrm{a}} \\
0.006^{\mathrm{b}}\end{array}$ & 0.01 & 0.05 & 2 & - \\
\hline EU-Directive 2013/39/EU [16] & 0.01 & 0.005 & 0.001 & 0.01 & 0.05 & 2 & \\
\hline USA [94] & 0.015 & 0.005 & 0.002 & 0.01 & 0.1 & - & \\
\hline Canada [95] & 0.01 & 0.005 & 0.001 & 0.01 & 0.05 & 1 & 5 \\
\hline
\end{tabular}

a For total mercury

b For inorganic mercury

of washed-out metals with exchanger sites in deeper layers of the water-saturated soil zone are neglected.

Soil microorganisms, invertebrates and sensitive plant species of the herb layer are predominantly found or rooted in the humus-rich $\mathrm{O}$ and $\mathrm{A}$ horizons. Therefore, for the $\mathrm{CL}(\mathrm{M})_{\text {eco }}$ and $\mathrm{CL}(\mathrm{Cd})_{(\text {food) }}$ the less thick biologically active soil layer (e.g.) is considered, where the water output (here referred to as soil water) is higher. The differential amount of water to the leachate flow below the root zone is absorbed in the deeper soil layers by plant roots and is subject to transpiration.

The leachate rate below the biologically active soil horizons $Q_{\mathrm{le}(\mathrm{zb})}$ was calculated as follows:

$$
Q_{\mathrm{le}(\mathrm{zb})}=Q_{\mathrm{le}(z)}+\left(1-f_{\mathrm{ET}(\mathrm{zb})}\right) *(P-(P * \mathrm{fi})),
$$

where $Q_{\text {le(zb) }}$ is the leachate rate below the biologically active soil horizons $(\mathrm{zb}) ; Q_{\mathrm{le}(\mathrm{z})}$, the leachate rate below the total rooted soil layer $(z)$ (corresponds to the rate from the leachate map of the BGR [25]; $P$, the precipitation (average annual sum over 30 years 1981-2010); $f_{\mathrm{ET}(\mathrm{zb})}$, the factor for determining the proportion of evapotranspiration from the biologically active soil layer (e.g.), and $\mathrm{fi}_{(\mathrm{zb})}$ is the factor for calculating the share of interception in annual precipitation. 19]:

$$
\begin{aligned}
& f_{\mathrm{ET}(\mathrm{zb})}=0.25 \text { for } \mathrm{CL}(\mathrm{Hg})_{\text {eco. }} \\
& f_{\mathrm{ET}(\mathrm{zb})}=0.5 \text { for } \mathrm{CL}(\mathrm{Pb})_{\text {eco }}, \mathrm{CL}(\mathrm{Cd})_{\text {eco }}, \mathrm{CL}(\mathrm{As})_{\mathrm{eco}}, \\
& \mathrm{CL}(\mathrm{Cu})_{\text {eco }}, \mathrm{CL}(\mathrm{Ni})_{\text {eco }}, \mathrm{CL}(\mathrm{Zn})_{\text {eco }}, \mathrm{CL}(\mathrm{Cr})_{\text {eco. }} \\
& \mathrm{fi}_{(\mathrm{zb})}=0.15 \text { for arable and grassland vegetation. } \\
& \mathrm{fi}_{(\mathrm{zb})}=0.25 \text { for red beech and hornbeam. } \\
& \mathrm{fi}_{(\mathrm{zb})}=0.20 \text { for all other deciduous trees. } \\
& \mathrm{fi}_{(\mathrm{zb})}=0.35 \text { for conifers. }
\end{aligned}
$$

Critical concentrations for the protection of human health Protection of drinking water

There are currently several legal limits or guideline values for the concentration of heavy metals in drinking water (Table 11).

The critical limits for heavy metals in drinking water specified in the Mapping Manual $[18,29,30]$ with reference to the WHO guideline [37] for $\mathrm{Pb}, \mathrm{Cd}, \mathrm{Hg}$ correspond to the limit values of the currently valid Drinking Water Ordinance for Germany [38]. For this reason, the limit concentrations of the Drinking Water Ordinance for Germany [38] were generally used for the CL(M) calculation in this project (Table 11, 1st line, italics type).

\section{Protection of vegetable foods (wheat grain)}

The EU limit value for cadmium in wheat grain of 0.2 $\left[\mathrm{mg} \mathrm{kg}^{-1}\right.$ ] (Commission of the European Communities (2001), EC No 466/2001) was not derived on the basis of effects. Therefore, in the present study, the cadmium limit value for wheat was used instead of the EU Regulation (EC No. 1881/2006) as recommended in the ICP Modeling and Mapping Manual [18] (Table 12, 2nd line) [19].

Since the concentration (critical limit) for the plant $\left([\mathrm{Cd}]_{\mathrm{ha}(\mathrm{crit}))}\right.$ is given, the critical concentration in the soil solution $\left([\mathrm{Cd}]_{\mathrm{sdw}(\mathrm{crit})}\right)$ can be determined iteratively with transfer functions according to Römpkens et al. [39] (details see [19]). [Cd $]_{\text {sdw(crit) }}$ is then $0.8\left[\mathrm{mg} \mathrm{m}^{-3}\right]$.

Table 12 Critical concentrations of cadmium in wheat

\begin{tabular}{llll}
\hline Directive or regulation & Object of protection & Unit & Cd \\
\hline $\begin{array}{l}\text { EU Regulation (EC No. 1881/2006) } \\
\text { [2] }\end{array}$ & Food products & $\mathrm{mg} \mathrm{kg}^{-1}$ & 0.2 \\
$\begin{array}{l}\text { Manual of the ICP Modeling and } \\
\text { Mapping [18] -2017) }\end{array}$ & Wheat grain & $\mathrm{mg} \mathrm{kg}^{-1}$ & 0.1 \\
\hline
\end{tabular}


Table 13 Coefficients for the calculation of the critical concentration of free ions as a function of the concentration of free ions with protective effect (=function of the pH value) according to De Vries et al. [51]

\begin{tabular}{llllll}
\hline Coefficients & $\mathbf{C d}$ & $\mathbf{P b}$ & $\mathbf{C u}$ & $\mathbf{N i}$ & $\mathbf{Z n}$ \\
\hline$a$ & -0.32 & -0.91 & -1.23 & -0.64 & -0.31 \\
$\gamma$ & -6.34 & -3.8 & -2.05 & -2.59 & -4.63 \\
\hline
\end{tabular}

\section{Critical concentrations for the protection of ecosystems} and biodiversity

The ecotoxicological effect of heavy metal ions depends on their concentration in soil water, as only free active ions are absorbed into the biomass and thus interact with the organisms. Hettelingh et al. [40] and Reinds et al. [33] compiled critical limits for heavy metals. The determination of the critical total concentration of heavy metals in soil water related to soil microorganisms, invertebrates and plants has to be carried out for each considered heavy metal according to its chemical properties according to different approaches as follows.

\section{Determination of critical concentration of free heavy metal} ions $\mathrm{Cd}, \mathrm{Pb}, \mathrm{Cu}, \mathrm{Zn}$ and $\mathrm{Ni}$ in soil solution

For a number of heavy metals $\left(\mathrm{Cd}^{2+}, \mathrm{Pb}^{2+}, \mathrm{Cu}^{2+}, \mathrm{Zn}^{2+}\right.$, $\mathrm{Ni}^{2+}$ ) toxicity is highly dependent on the simultaneous presence of non-toxic cations $\left(\mathrm{Na}^{+}, \mathrm{Ca}^{2+}, \mathrm{H}^{+}\right)$which restrict the uptake of toxic heavy metals into organisms and thus protect them. The concentration of the protective competing cations is closely correlated with the $\mathrm{pH}$ value. The concentration of free heavy metal ions (Table 13) is therefore a function of the $\mathrm{pH}$ value of the soil water: $\log [M]_{\text {freeswd(crit) }}=\alpha \cdot p H+\gamma \cdot[41,42]$.

Calculation of critical total concentrations of reactive metals in soil for $\mathrm{Cd}, \mathrm{Pb}, \mathrm{Cu}, \mathrm{Zn}, \mathrm{Ni}$.

Metals occur in soil water not only as free ions, but also in the form of soluble complexes:

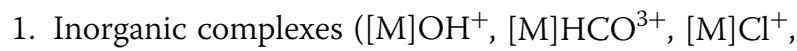
etc.);

2. Metals bound to the dissolved organic mass (DOM) $\left([\mathrm{M}]_{\mathrm{DOM}}\right)$;

3. Metals bound to suspended particles (SPM) $\left([\mathrm{M}]_{\mathrm{SPM}}\right.$.

After the critical limit functions for the concentration of free heavy metal ions have been derived, the next step for the critical load calculation was to derive the critical total concentrations in the soil solution $[\mathrm{M}]_{\mathrm{swd}(\mathrm{crit})}$ (eco), which is required for the calculation of the tolerable leaching. Manual chapter 5.5 [30] recommends that this transformation be performed using a chemical specification model, e.g. the Windemere Humic Aqueous Model,
Table 14 Assignment matrix of pH classes from BÜK1000N to an average $\mathrm{pH}$ value per horizon of the soil profiles according to KA5 ([45]. p. 367)

\begin{tabular}{llll}
\hline $\begin{array}{l}\text { pH classes original } \\
\text { from BÜK1000N }\end{array}$ & $\mathbf{p H}\left(\mathrm{CaCl}_{\mathbf{2}}\right)$ of & $\mathbf{p H}\left(\mathrm{CaCl}_{\mathbf{2}}\right)$ to & $\begin{array}{l}\mathbf{p H}\left(\mathrm{CaCl}_{\mathbf{2}}\right) \\
\text { middle }\end{array}$ \\
\hline $\mathrm{a} 0 / \mathrm{s} 0$ & 6.8 & 7.2 & 7 \\
$\mathrm{a} 1$ & 7.2 & 7.9 & 7.6 \\
s1 & 6.1 & 6.8 & 6.4 \\
s2 & 5.4 & 6.1 & 5.8 \\
s3 & 4.7 & 5.4 & 5.0 \\
s4 & 4 & 4.7 & 4.4 \\
s5 & 3.3 & 4 & 3.6 \\
\hline
\end{tabular}

Table 15 Classification matrix of base saturation to an average pH value per horizon of the guide soil profiles according to KA5 ([45].p. 371)

\begin{tabular}{lclll}
\hline BS (\%) of & $\mathbf{B S}(\%)$ to & $\mathbf{p H}\left(\mathrm{CaCl}_{\mathbf{2}}\right)$ of & $\mathbf{p H}\left(\mathrm{CaCl}_{\mathbf{2}}\right)$ to & $\begin{array}{l}\mathbf{p H}\left(\mathrm{CaCl}_{\mathbf{2}}\right) \\
\text { middle }\end{array}$ \\
\hline 0.1 & 5 & 2.8 & 3.3 & 3.1 \\
6 & 20 & 3.3 & 3.8 & 3.6 \\
21 & 50 & 3.8 & 4.8 & 4.3 \\
51 & 80 & 4.8 & 6 & 5.4 \\
81 & 100 & 6 & 8 & 7 \\
\hline
\end{tabular}

WHAM [43, 44]. This model (version 6) was specially adapted to the requirements of the critical limit derivation for soils (W6S-MTC2). For the German data set of the critical load for $\mathrm{Cd}, \mathrm{Pb}, \mathrm{Cu}, \mathrm{Zn}$ and $\mathrm{Ni}$, the critical total concentrations were calculated with the latest model version on the basis of the site-specific input data required for this, which are described below.

\section{pH levels}

In the database of the BÜK1000N [21] on the soil profiles, $\mathrm{pH}$ classes are given for each horizon of the profiles of the grassland and arable land use types. These classes can be transformed in $\mathrm{pH}\left(\mathrm{CaCl}_{2}\right)$ ranges according to the Soil Science Mapping Guide KA5 [45], from which the mean value can be assigned to each horizon ${ }^{4}$ (Table 14). Subsequently, the depth step-weighted mean value was calculated over the horizons up to the considered depth, i.e. over the $\mathrm{O}$ and $\mathrm{A}$ horizons.

The database on soil profiles does not contain $\mathrm{pH}$ data for the profiles of the forest use type, but the concentrations of the exchangeable cations, from which the base

\footnotetext{
${ }^{4}$ If a logarithmic method were used to calculate the mean value, e.g. de-logarithmic-averaging-logarithmic, a $\mathrm{pH}$ value of 4.18 would result instead of an average value of $\mathrm{pH} 4.2$. In view of the classification into ranges of $0.7 \mathrm{pH}$ units, this deviation has no significant influence on the results.
} 
Table 16 Assignment of the organic mass content to the horizons of the soil profiles of BÜK1000N, based on the humus class data

\begin{tabular}{|c|c|c|c|}
\hline Land use & $\begin{array}{l}\text { Humus class from BÜK1000N (BGR [21] } \\
\text { 2014) }\end{array}$ & Organic matter content OM Mass $\%$ of & $\begin{array}{l}\text { Organic matter } \\
\text { content OM } \\
\text { Mass \% to }\end{array}$ \\
\hline Forests & ho & 0 & 0 \\
\hline Forests & h1 & 0.1 & 1 \\
\hline Forests & h2 & 1.1 & 1.9 \\
\hline Forests & h3 & 2 & 4.9 \\
\hline Forests & h4 & 5 & 9.9 \\
\hline Forests & h5 & 10 & 14.9 \\
\hline Forests & h6 & 15 & 29.9 \\
\hline Forests & h7 & 30 & 55 \\
\hline Arable land & ho & 0 & 0 \\
\hline Arable land & h1 & 0.1 & 1 \\
\hline Arable land & h2 & 1.1 & 1.9 \\
\hline Arable land & h3 & 2 & 3.9 \\
\hline Arable land & h4 & 4 & 7.9 \\
\hline Arable land & h5 & 8 & 14.9 \\
\hline Arable land & h6 & 15 & 29.9 \\
\hline Arable land & h7 & 30 & 55 \\
\hline Grassland & ho & 0 & 0 \\
\hline Grassland & h1 & 0.1 & 1 \\
\hline Grassland & h2 & 1.1 & 1.9 \\
\hline Grassland & h3 & 2 & 3.9 \\
\hline Grassland & h4 & 4 & 7.9 \\
\hline Grassland & h5 & 8 & 14.9 \\
\hline Grassland & h6 & 15 & 29.9 \\
\hline Grassland & h7 & 30 & 55 \\
\hline
\end{tabular}

saturation can be calculated according to KA5 [45], p. 371. The $\mathrm{pH}\left(\mathrm{CaCl}_{2}\right)$ range could again be derived from the base saturation (Table 15), so that the procedure could then be followed as described above.

\section{Organic matter content (OM)}

A humus class is specified horizontally in the database for the soil profiles. According to KA5 [45], p. 112, a range for the content of organic matter was assigned to each humus class, differentiated according to type of use (Table 16). Subsequently, the horizontal minimum contents (conservatively) were averaged to the considered depth.

\section{Determination of the content of dissolved organic carbon (DOC) and dissolved organic substance (DOM)}

There is currently no data available on soils in connection with the vegetation type for this purpose that would be representative and thus transferable to the soil forms and vegetation types occurring in Germany. Therefore, the recommendation in the ICP Modeling and Mapping
Manual [18, 29, 30], Chapter 5.5) for "default" values for forest, grassland and arable land was used (Table 17). For forest soils, a differentiation of the DOC contents according to coniferous and deciduous forest as well as according to depth levels according to De Vries et al. [46]: Appendix 11 is available.

Table 17 Classification of dissolved carbon (DOC) contents as a function of vegetation type

\begin{tabular}{llll}
\hline & \multicolumn{2}{l}{ DOC $\left[\mathbf{m g ~ I}^{-\mathbf{1}}\right]$} \\
\cline { 2 - 4 } Depth step: & $\mathbf{- 5}$ to $\mathbf{0}$ & $\mathbf{0 - 1 0}$ & $\mathbf{0 - 3 0}$ \\
\hline Coniferous forest $^{\mathrm{a}}$ & 40 & 23 & 16 \\
Deciduous forest $^{\mathrm{a}}$ & 32 & 21 & 12 \\
Mixed forest & 36 & 22 & 14 \\
Grassland $^{\mathrm{b}}$ & & 15 & \\
Field $^{\mathrm{b}}$ & & & 10 \\
\hline
\end{tabular}

Sources: ${ }^{\text {a }}$ deVries et al. [46]. ${ }^{\text {b }}$ Manual of ICP Modeling and Mapping [18, 29, 30]: Chapter 5.5) 
Table 18 Assignment of the factor of the multiple of the atmospheric $\mathrm{CO}_{2}$ partial pressure to the depth levels of the guide soil profiles of the BÜK1000N, based on the information in the manual of the ICP Modeling and Mapping $[18,29,30]$

\begin{tabular}{lll}
$\begin{array}{l}\text { Upper depth } \\
{[\mathbf{c m}]}\end{array}$ & $\begin{array}{l}\text { Lower depth } \\
{[\mathbf{c m}]}\end{array}$ & $\begin{array}{l}\text { Multiplication factor } \\
\text { with the atmospheric } \mathrm{CO}_{\mathbf{2}} \\
\text { partial pressure }\end{array}$ \\
\hline 0 & 5 & 5.0 \\
5 & 10 & 5.0 \\
10 & 15 & 6.7 \\
15 & 20 & 7.5 \\
20 & 25 & 8.0 \\
25 & 30 & 8.3 \\
30 & 35 & 10.0 \\
35 & 40 & 11.3 \\
40 & 45 & 12.2 \\
45 & 50 & 13.0 \\
50 & 55 & 13.6 \\
55 & 60 & 14.2 \\
\hline
\end{tabular}

In the manual of the ICP Modeling and Mapping $[18,29,30]$, Chapter 5.5) it is stated that the content of organic matter (DOM) is about twice the DOC content.

\section{Partial pressure of $\mathrm{CO}_{2}$ in the soil solution $\left(\mathrm{pCO}_{2}\right)$}

The partial pressure of $\mathrm{CO}_{2}$ in the soil solution is generally higher than in the atmosphere above, because $\mathrm{CO}_{2}$ in the soil is released by the plants through respiration, thus increasing the pressure in the soil. The manual of the ICP Modeling and Mapping [18, 29, 30], Chapter 5.5 provides simplifying estimates based on extensive regional studies: 5-10 times atmospheric $\mathrm{CO}_{2}$ partial pressure for organic horizons, 5-15 times atmospheric $\mathrm{CO}_{2}$ partial pressure for A horizons, 15-20 times atmospheric $\mathrm{CO}_{2}$ partial pressure for $\mathrm{B}$ horizons, 15-30 times atmospheric $\mathrm{CO}_{2}$ partial pressure for $\mathrm{C}$ horizons.

Taking into account the depth levels of the horizons described in the BÜK1000N [21], the following allocation matrix for the factor of the multiple of the atmospheric $\mathrm{CO}_{2}$ partial pressure was established for this project, which was produced by interpolation of the estimated figures given in the manual (Table 18). Subsequently, the depth step-weighted mean value was calculated up to the considered depth.

\section{Concentration of suspended particles (SPM)}

For the CL(M) data set, it was assumed for reasons of simplification that the concentration of suspended particles (SPM) in the soil solution is negligibly low. PSM was therefore set to ZERO in all analysis cells in Germany.
Table 19 Total critical concentration of heavy metal ions that can be used independently of $\mathrm{pH}$

\begin{tabular}{llll}
\hline Object of protection & Unit & As & Cr \\
\hline Ecosystems & $\mu \mathrm{gl}^{-1}$ & 70 & 44 \\
\hline
\end{tabular}

\section{Calculation of the critical total concentration of $\mathrm{Hg}$} in the soil solution

Mercury occurs as far as possible only bound to humus complexes, so that it is not necessary to determine the free ion concentration in the soil solution. Thus, it makes sense to determine the critical concentration of $\mathrm{Hg}$ below the humus layer, in particular of forests, by relating the critical concentration to the organic matter content. On this basis, the critical concentration (only of humusbound ions) in the soil solution $[\mathrm{Hg}]_{\text {swd(crit)eco }}\left[\mathrm{mg} \mathrm{m}^{-3}\right]$ can be determined according to the following equation:

$$
[\mathrm{Hg}]_{\text {swd(crit)eco }}=[\mathrm{Hg}]_{\mathrm{OM}(\text { crit })} \cdot \mathrm{f}_{\mathrm{f}} \cdot[\mathrm{DOM}]_{\mathrm{swd}} \text {, }
$$

with $[\mathrm{Hg}]_{\mathrm{OM}(\mathrm{crit})}$ as the critical limit for $\mathrm{Hg}$ based on solid organic substance (OM) in humus layer; $f_{f}$, the factor to describe the ratio of $\mathrm{Hg}$ in solid organic substance $(\mathrm{OM})$ to $\mathrm{Hg}$ in dissolved organic matter (DOM) [-], and $[\mathrm{DOM}]_{\mathrm{swd}}$ as the concentration of dissolved organic matter in the soil solution of humus layer $\left[\mathrm{g} \mathrm{m}^{-3}\right]$.

Meili et al. [47] recommend the critical limit of $0.5 \mathrm{mg}$ $\mathrm{Hg} \mathrm{kg}^{-1} \mathrm{OM}$ [18]. This results in an $\mathrm{Hg} / \mathrm{OM}$ ratio of $0.0000005 \mathrm{~kg} \mathrm{~kg}^{-1}$. The calculation of $[\mathrm{Hg}]_{\text {swd(criteco) }}$ also requires information on the ratio of $\mathrm{Hg}$ concentrations in solid and dissolved organic matter $\left(f_{\mathrm{f}}\right)$ and on the concentration of DOM in the soil solution $[\mathrm{DOM}]_{\mathrm{swd}}$. A Swedish study [47-49] showed that the concentration of $\mathrm{Hg}$ in solid and dissolved organic matter is usually approximately the same even under different environmental conditions (soil, climate), so that according to the current state of knowledge the value $f_{f}=1$ can be defined as standard. The allocation of [DOM] was made on the basis of a Table 17, whereby the DOC contents for the calculation of $[\mathrm{DOM}]$ were doubled.

\section{Determination of the critical total concentration} of the heavy metal ions As and $\mathrm{Cr}$ in the soil solution Ecotoxicological effects of arsenic on ecosystem compartments could be excluded by Doyle et al. [50] at a value of $70 \mu \mathrm{g} \mathrm{l}^{-1}$ in soil water (no-effect value-ENEV) (Table 19). A dependence of this no-effect value on soil chemical parameters could not be determined, so that a critical limit function is unnecessary.

For Cr, De Vries et al. [51] and Lofts et al. [42] could not find sufficient data to parameterise a function of the 
Table 20 Overview of the 5, 25, 50, 75 and 95 percentiles, minima and maxima as well as arithmetic mean values of the critical loads in the receptor areas in Germany

\begin{tabular}{|c|c|c|c|c|c|c|c|c|}
\hline & $\begin{array}{l}\text { Nickel } \\
\mathrm{g} \mathrm{ha}^{-1} \mathrm{a}^{-1}\end{array}$ & Copper & Zinc & Lead & Arsenic & Chrome & Cadmium & Mercury \\
\hline \multicolumn{9}{|c|}{ Drinking water } \\
\hline Min & & 484 & 1234 & 3 & 2 & 12 & 0.8 & 0.3 \\
\hline 5 Perc. & & 1070 & 2848 & 9 & 6 & 28 & 2.5 & 0.6 \\
\hline 25 Perc. & & 4091 & 10428 & 24 & 21 & 104 & 7.1 & 2.1 \\
\hline 50 Perc. & & 6172 & 15,628 & 35 & 31 & 156 & 10.2 & 3.2 \\
\hline Mean & & 6168 & 15,609 & 35 & 31 & 156 & 10.2 & 3.2 \\
\hline 75 Perc. & & 7956 & 20,093 & 44 & 40 & 200 & 12.9 & 4.1 \\
\hline 95 Perc. & & 11,268 & 28,316 & 61 & 56 & 282 & 18 & 5.7 \\
\hline Max & & 27,533 & 69,133 & 142 & 138 & 688 & 42.6 & 13.8 \\
\hline \multicolumn{9}{|c|}{ Ecosystems } \\
\hline Min & 37 & 7 & 81 & 2 & 115 & 78 & 1.5 & 0.1 \\
\hline 5 Perc. & 109 & 13 & 189 & 6 & 181 & 115 & 4.1 & 0.2 \\
\hline 25 Perc. & 197 & 27 & 313 & 9 & 311 & 198 & 6.4 & 0.3 \\
\hline 50 Perc. & 518 & 74 & 565 & 21 & 414 & 263 & 10.5 & 0.4 \\
\hline Mean & 981 & 158 & 543 & 122 & 421 & 267 & 15.6 & 0.4 \\
\hline 75 Perc. & 1363 & 118 & 695 & 102 & 501 & 317 & 20.9 & 0.4 \\
\hline 95 Perc. & 3338 & 710 & 1032 & 601 & 711 & 448 & 42.4 & 0.6 \\
\hline Max & 11,232 & 3384 & 2457 & 2603 & 1669 & 1049 & 127.6 & 1.1 \\
\hline \multicolumn{9}{|c|}{ Food (wheat products) } \\
\hline Min & & & & & & & 1.9 & \\
\hline 5 Perc. & & & & & & & 3 & \\
\hline 25 Perc. & & & & & & & 4.9 & \\
\hline 50 Perc. & & & & & & & 6 & \\
\hline Mean & & & & & & & 6.1 & \\
\hline 75 Perc. & & & & & & & 7.1 & \\
\hline 95 Perc. & & & & & & & 9.3 & \\
\hline Max & & & & & & & 19.2 & \\
\hline
\end{tabular}

critical concentration and therefore recommend the lowest effect-based threshold value (for an invertebrate species in fresh water) of $44 \mu \mathrm{g} \mathrm{l} \mathrm{l}^{-1}$ (Table 19).

However, the adoption of impact thresholds from investigations in water bodies for anhydromorphic sites is controversial (Advisory Committee for Existing Substances "Risk Assessment of Substances in Soils" [52]) and can only be used as an alternative under the simplistic assumption that the sensitivity of biota in water bodies is comparable with the sensitivity of microorganisms in soil water [53].

\section{Results}

Spatial patterns of critical load calculation for $\mathrm{Pb}, \mathrm{Cd}, \mathrm{Hg}$, $\mathrm{As}, \mathrm{Cu} \mathrm{Ni}, \mathrm{Zn}$ and $\mathrm{Cr}$

Additional file 1: Figures S1.1, S1.2, S1.3, S1.4, S1.5, S1.6, S1.7, S1.8, S1.9, S1.10, S1.11, S1.12, S1.13, S1.14, S1.15 show the results of the critical load calculation for the heavy metals lead, cadmium, mercury, arsenic, copper, nickel, zinc and chromium in cartographic form.

\section{Statistical distribution of critical loads}

Table 20 shows the results of statistic evaluation of the area-based critical load calculation.

It can be seen that the sensitivity of the different objects of protection for the same heavy metal can vary in magnitudes. For example, for copper, zinc and mercury the sensitivity of ecosystems is higher than the requirements for drinking water protection, for arsenic, chromium and cadmium it is vice versa. With regard to lead, the CL range for drinking water protection is within the CL range for ecosystem protection. $\mathrm{CL}(\mathrm{Cd})_{\text {food }}$ for wheat products is significantly lower than $\mathrm{CL}(\mathrm{Cd})_{\text {drink }}$ for drinking water or ecosystem protection. 


\section{Validity \\ Soil yield potential}

The best available yield statistics are available in summary form for the administrative districts of Germany. These statistics do not provide a direct basis for this study because the arable crops and their yields are not broken down by soil type (or group). The approach taken by Knappe et al. [54] of combining the area shares of arable crops in a county with the area shares of soil forms of the BÜK1000 in a county according to the area shares of arable crops may allow a snapshot to be taken, as was be the aim in the study by Knappe et al. [54]. However, this is not sufficient for a long-term forecast of soil-typical yields of the various arable crops. For this reason, the more or less long-term unchangeable soil-specific yield potentials were estimated in this study. This approach is also the basis of the map of the "Arable yield potential of soils in Germany" [34] based on the "Soil Quality Rating" (SQR) [35]. This map was compared with the results of the present study. Where plausible differences were found in relation to the influence of groundwater and backwater and in relation to rootability in Table 6, the assessment in the present study was adapted to the map of the 'arable yield potential of soils in Germany' [34].

The largest differences in the valuation result from the Münsterland, Ostfriesland and Oderhaff regions. This applies to the areas with the BÜK1000N soil form "Mainly Gley podzol and Gleye, low distribution of podzols from sandy river sediments; low distribution of Plaggen ash and Treposole" with a reference profile PP (norm podzol) for field use. The relevant horizon to a depth of $30 \mathrm{~cm}$ (Aep) consists of weakly loamy sand. The yield potential calculated here is 2.94 (on the scale between 1 and 5), which corresponds to 49 points on the BGR scale (on the scale between 0 and 102). The BGR card shows $60-80$ points for the same areas. Reasons for the far more positive evaluation by the BGR could not be determined, therefore no adjustment of the evaluation to the BGR was made for this profile. At the same time, the BGR also indicates the same yield potential of $60-80 \%$ for cambisol vega from clayey loamy floodplain sediments in the Oderbruch as for podzol from 60 to $80 \%$ for arable land use. According to the method used in this study, a relative yield potential of 3.86 (on the scale between 1 and 5) results for this soil form in the Oderbruch; this corresponds to 73 points on the BGR scale (on the scale between 0 and 102). In the case of the cambisol vega, the assessments of both procedures are well in line.

Another significant difference is shown by the evaluation of the "Predominantly Chernosema" with a reference profile TTn (Norm Chernosema) for arable land use in the Magdeburger Börde. With the method for this study, a yield potential of 3.6 (=66 BGR points) was determined, while the BGR card represents $>80$ points. The reference profile shows a strongly clayey silt for the Ap horizon. With the method used here, the danger of waterlogging due to the high clay content (Table 6) is evaluated negatively, while the BGR does not evaluate this hazard indicator negatively for this soil profile. In this case, too, no adjustment was made to the BGR valuation. Areas for which higher yield potentials were determined in the present study than in the BGR map are not identifiable. In this respect, the possible underestimation of yields always leads to lower critical loads and these are thus "on the safe side". If, however, the areas with the greatest deviations from the yield potential of the BRGs were taken as a basis, i.e. the yield potential for the slightly loamy-sandy podzol in the Münsterland was 70 points according to BGR (corresponds to 3.75 on the scale from 1 to 5$)$, the following changes in $\mathrm{CL}(\mathrm{M})_{\text {eco }}$ would result for wheat, barley and rapeseed, for example (Table 21).

If the BGR assessment of the yield potential is applied to determine the yield, which in extreme cases is approx. $28 \%$ higher, the ecosystem-related critical loads for lead, cadmium, mercury, nickel, zinc, arsenic, copper and chromium would only increase by a few percentage points. The highest deviation is $5.9 \%$ for the critical load for copper on wheat fields.

The yields of arable crops, as used in the present case to calculate critical loads, are subject to greater variation than the wood yields of forests and grassland yields, as actual arable yields are used instead of potential wood and grassland yields (Sect. 3.5). While in the forests and semi-natural grassland a tendency towards extensification of production has been apparent for several years, this is not evident in arable farming. While in forests and natural open land nitrogen inputs from the air are decreasing, more nitrogen is fertilised on fields.

\section{Heavy metal concentration in harvested crop}

Literature studies on heavy metal contents in the harvestable parts of agricultural crops have already been carried out in earlier projects $[55,56]$. The calculated median values for the $\mathrm{Cd}, \mathrm{Pb}$ and $\mathrm{Hg}$ contents in cereal grain, beet, potatoes, maize, grass and other forage plants, oil and legume seeds are significantly higher than the values used for the calculations in this paper. The earlier data bases [19] for calculating mean concentrations (medians) in crop plants date from the late 1980s [57] and early 1990s [58]. Since then, the deposition of heavy metals, especially $\mathrm{Pb}$, has decreased. This has led to lower concentrations later [54]. The median values used here for the concentrations of lead, cadmium and mercury are taken from Knappe et al. [54], p. D 59 for arable crops. However, the authors also indicate higher concentrations of 


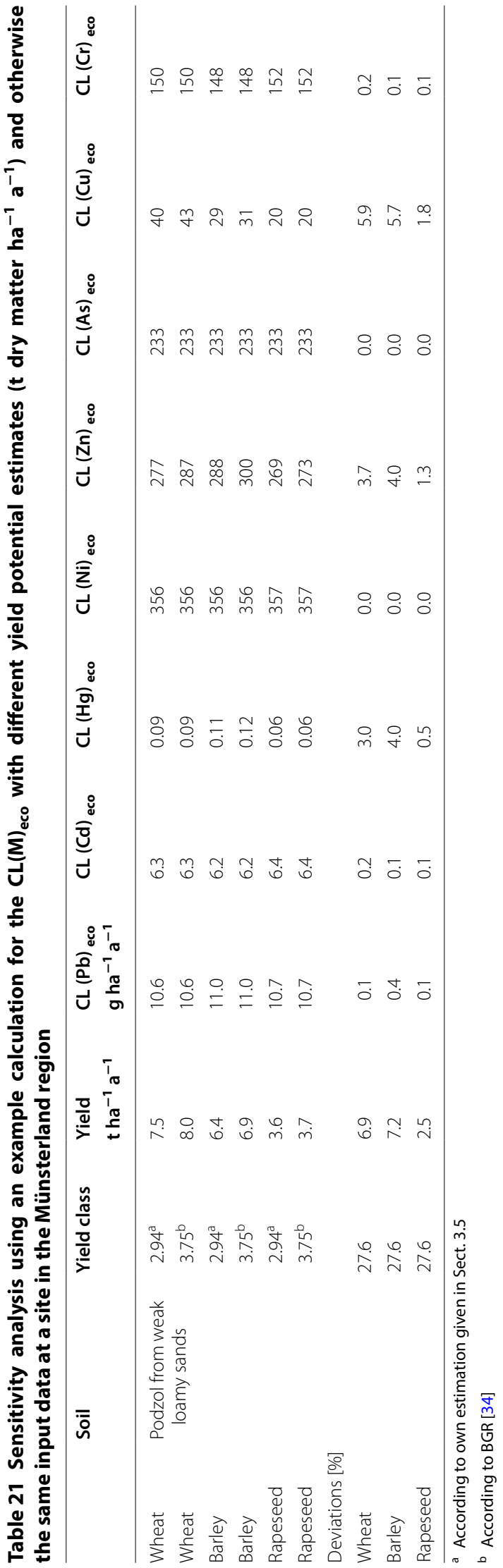


Table 22 Sensitivity analysis using an example calculation for $\mathrm{CL}(\mathrm{Pb})_{\text {eco }}$ with different $\mathrm{Pb}$ contents and otherwise the same input data at a site with cambisol vega from clayey loamy outer sediments in the subcontinental climate zone

\begin{tabular}{|c|c|c|c|c|c|c|}
\hline & Yield & t dry mass ha-1 $a^{-1}$ & $\begin{array}{l}\text { Silage maize } \\
46.0\end{array}$ & $\begin{array}{l}\text { Sugar beets } \\
67.8\end{array}$ & $\begin{array}{l}\text { Wheat } \\
8.0\end{array}$ & $\begin{array}{l}\text { Barley } \\
6.9\end{array}$ \\
\hline \multirow{2}{*}{$\begin{array}{l}\text { Input data and results } \\
\text { used in this paper }\end{array}$} & $\mathrm{Pb}$ content $\mathrm{a}^{\mathrm{a}}$ & $\mathrm{gt}^{-1}$ & 0.2 & 0.2 & 0.03 & 0.1 \\
\hline & $\mathrm{CL}(\mathrm{Pb})_{\mathrm{eco}}$ & $\mathrm{gha}^{-1} \mathrm{a}^{-1}$ & 10.9 & 15.3 & 2.0 & 2.4 \\
\hline \multirow{2}{*}{$\begin{array}{l}\text { Alternative input data } \\
\text { and results }\end{array}$} & $\mathrm{Pb}$ content ${ }^{\mathrm{b}}$ & $\mathrm{gt}^{-1}$ & 0.6 & 0.44 & 0.14 & 0.21 \\
\hline & $\mathrm{CL}(\mathrm{Pb})_{\mathrm{eco}}$ & $g h a^{-1} a^{-1}$ & 25.2 & 71.6 & 2.4 & 3.3 \\
\hline \multirow[t]{2}{*}{ Deviations } & $\mathrm{Pb}$ content & $\%$ & 300 & 220 & 466 & 210 \\
\hline & $\mathrm{CL}(\mathrm{Pb})_{\mathrm{eco}}$ & $\%$ & 169 & 106 & 45 & 32 \\
\hline
\end{tabular}

${ }^{a}$ According to Knappe et al. [54]. p. D59ff, medians, as used in this present study

b According to Knappe et al. [54]. p. D 59ff, 90 Perz

Table 23 Sensitivity analysis using an example calculation for the $\mathrm{CL}(\mathrm{Cd})$ eco $_{\text {with }}$ different cadmium contents in stem wood with bark and otherwise the same input data at a site in the subcontinental climate zone

\begin{tabular}{|c|c|c|c|c|}
\hline Tree species & Soil & $\begin{array}{l}\text { Yield } \\
\text { t ha }^{-1} a^{-1}\end{array}$ & $\begin{array}{l}\text { Cd content } \\
\mathrm{g} \mathrm{t}^{-1} \text { dry mass }\end{array}$ & $\begin{array}{l}\mathrm{CL}(\mathrm{Cd}) \text { eco } \\
\mathrm{g} \mathrm{ha}^{-1} \mathrm{a}^{-1}\end{array}$ \\
\hline \multirow[t]{2}{*}{ Pine } & Cambisol from sands & 1.7 & $1.31^{\mathrm{a}}$ & 7.36 \\
\hline & & & $0.3^{b}$ & 5.62 \\
\hline Deviations in \% & & & -77.1 & -23.6 \\
\hline
\end{tabular}

a According to Jacobson et al. [32], as used in this present investigation

${ }^{b}$ According to ICP Modeling and Mapping Manual $[18,29,30]$

lead in the usual arable crops on the market (90 s percentiles) (Table 22).

The critical loads for lead (ecosystem related) in the example would increase by up to $169 \%$ compared to the $\mathrm{CL}(\mathrm{Pb})_{\text {eco }}$ determined here if the 90 percentile of lead concentrations according to Knappe et al. [54] were applied, which in this case are $300 \%$ higher than those used here. In particular, the $\mathrm{Cu}, \mathrm{Cr}$ and $\mathrm{Ni}$ contents in the stem wood of typical tree species in Germany are significantly dependent on the concentration in the soil [59]. Therefore, in this study, the low values published by Jacobsen et al. [32] were included in the CL calculation, which corresponds to the worst case. An exception is the $\mathrm{Cd}$ content in stem wood with pine bark. The median value from 45 studies by Jacobsen et al. [32] deviates more than four times from the range shown in the manual. For this reason, the sensitivity of the critical load is also shown for the low Cd content in the pine stem according to the ICP Manual [18] using an example (Table 23).

If one assumes the lowest value reported in the literature (manual of the ICP Modeling and Mapping-[18] for the $\mathrm{Cd}$ content, which deviates by $-77 \%$ from the value used here according to Jacobsen et al. [32], the $\mathrm{CL}(\mathrm{Cd})_{\text {eco }}$ would decrease by around $24 \%$. The contents of the heavy metals vary predominantly depending on the metal content in the soil. For example, the arsenic content in wheat varies from 0.01 to $0.34 \mathrm{mg} \mathrm{kg}^{-1}$ dry mass, in maize from 0.06 to $0.47 \mathrm{mg} \mathrm{kg}^{-1}$ dry mass and in grassland from 0.07 to $1.11 \mathrm{mg} \mathrm{kg}^{-1} \mathrm{dry}$ mass [60]. The copper content in wheat varies from 3.8 to $6.17 \mathrm{mg} \mathrm{kg}^{-1}$ dry mass, in maize from 1.9 to $7 \mathrm{mg} \mathrm{kg}^{-1}$ dry mass and in grassland from 6.4 to $21.5 \mathrm{mg} \mathrm{kg}^{-1}$ dry mass [61]. The zinc content in wheat ranges from 33 to $94 \mathrm{mg} \mathrm{kg}^{-1}$ dry mass, in maize from 28 to $174 \mathrm{mg} \mathrm{kg}^{-1}$ dry mass and in grassland from 38 to $176 \mathrm{mg} \mathrm{kg}^{-1}$ dry mass [61].

The zinc contents according to Knappe et al. [54], p. D 59ff (Sect. 3.5) used in the present study are partly at approx. $60 \%$ of the lower range limit stated by Van Driel et al. [61], but significantly higher for grassland. The arsenic contents applied here according to Knappe et al. [54], p. D 59 ff are for wheat only $30 \%$, but for maize and grass $200 \%$ of the lower range limits according to Wiersma et al. [60]. The copper contents according to Knappe et al. [54], p. D 59ff used for the CL calculation in this paper are higher for wheat and maize, but somewhat lower for grassland than the lower range limits according to Van Driel et al. [61]. The effect of applying older data for metal concentrations on the respective critical load for the protection of the ecosystem is calculated using an example area with a very high yield potential, where the highest deviations in terms of metal uptake are to be expected. 
Table 24 Sensitivity analysis using an example calculation for $\mathrm{CL}(\mathrm{M})_{\text {eco }}$ with different metal contents and otherwise the same input data at a site with cambisol vega from clayey-loamy sediments in the subcontinental climate zone

\begin{tabular}{|c|c|c|c|c|c|c|c|c|c|}
\hline & \multicolumn{3}{|c|}{$\begin{array}{l}\text { Alternative, older input data } \\
\text { and results }\end{array}$} & \multicolumn{3}{|c|}{$\begin{array}{l}\text { Input data and results used in this } \\
\text { study }\end{array}$} & \multicolumn{3}{|c|}{ Deviations [\%] } \\
\hline & Wheat & Silage maize & Meadow & Wheat & Silage maize & Meadow & Wheat & Silage maize & Meadow \\
\hline Zn content $\left[\mathrm{g} \mathrm{t}^{-1}\right]$ & $33^{b}$ & $28^{\mathrm{b}}$ & $38^{b}$ & $20^{c}$ & $19^{c}$ & $49.5^{c}$ & 65 & 47 & -23 \\
\hline As content $\left[\mathrm{g} \mathrm{t}^{-1}\right]$ & $0.01^{\mathrm{a}}$ & $0.06^{\mathrm{a}}$ & $0.07^{\mathrm{a}}$ & $0.035^{c}$ & $0.035^{c}$ & $0.1^{c}$ & -71 & 71 & -30 \\
\hline Cu content $\left[\mathrm{g} \mathrm{t}^{-1}\right]$ & $3.8^{\mathrm{b}}$ & $1.9^{\mathrm{b}}$ & $6.4^{b}$ & $4.6^{c}$ & $3.5^{c}$ & $6.2^{c}$ & -17 & -46 & 3 \\
\hline $\mathrm{CL}(\mathrm{Zn})_{\text {eсо }}\left[\mathrm{g} \mathrm{ha} \mathrm{g}^{-1} \mathrm{a}^{-1}\right]$ & 286.7 & 1309.4 & 311.5 & 182.1 & 895.3 & 399.3 & 57 & 46 & -22 \\
\hline$C L(A s)_{\text {eco }}\left[g h^{-1} a^{-1}\right]$ & 38.6 & 41.3 & 39.0 & 38.8 & 40.1 & 39.3 & -0.5 & 2.9 & -0.6 \\
\hline $\mathrm{CL}(\mathrm{Cu})_{\text {eco }}\left[\mathrm{g} \mathrm{ha} \mathrm{g}^{-1} \mathrm{a}^{-1}\right]$ & 31.5 & 88.4 & 49.9 & 38.0 & 162.0 & 48.3 & -17 & -45 & 3 \\
\hline
\end{tabular}

${ }^{a}$ According to Wiersma et al. [60]

${ }^{b}$ According to Van Driel et al. [61]

c According to Knappe et al. [54]

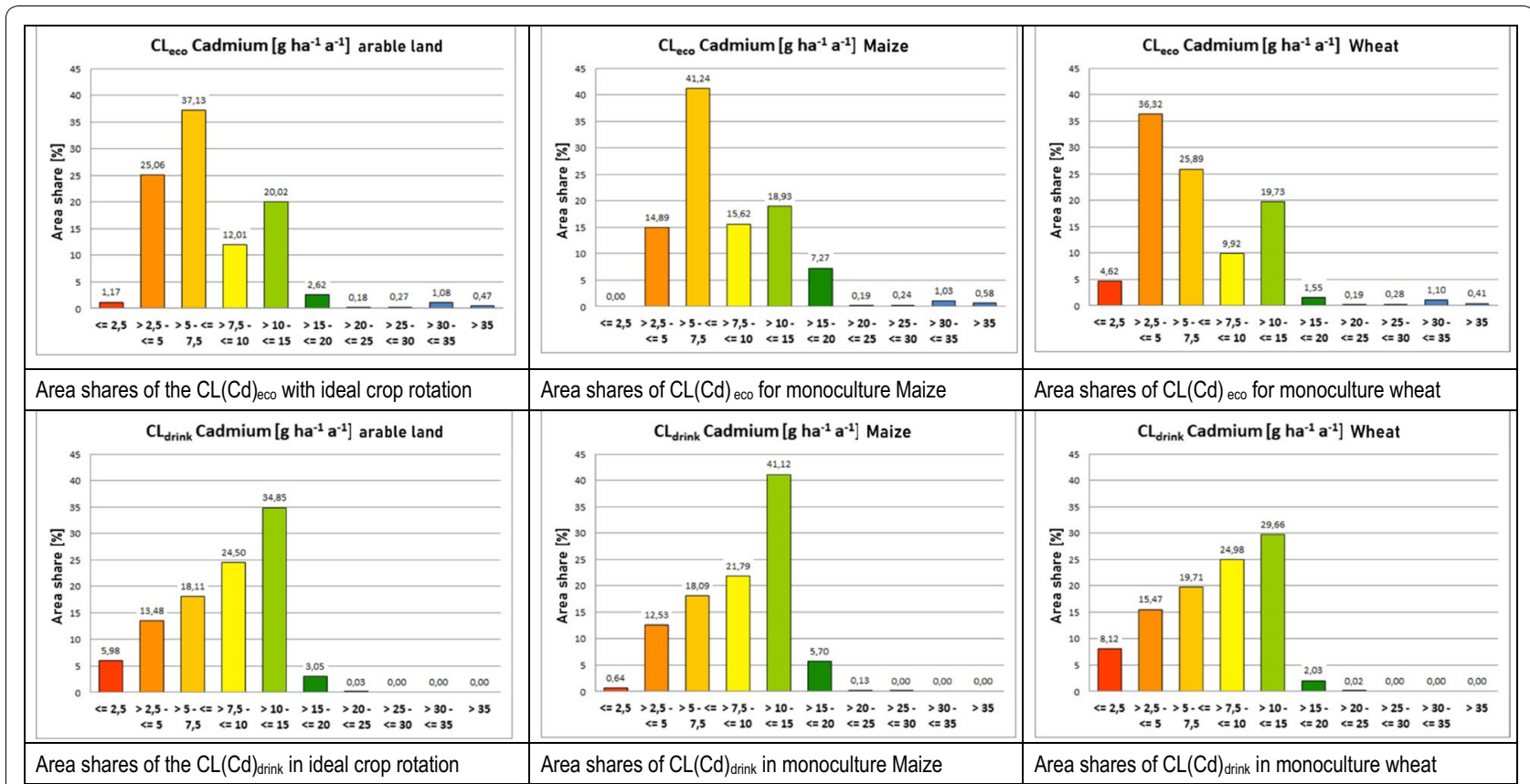

Fig. 1 Comparison of the area share in Germany in the critical load classes for cadmium for the protected goods ecosystem (CL(Cd) eco) and drinking water $\left(\mathrm{CL}(\mathrm{Cd})_{\text {drink }}\right)$, in each case in the variants "crop rotation according to good professional practice" (left), "monoculture maize" (centre), "monoculture wheat" (right)

The greatest negative differences between the contents used in this study and the older lower range limits mentioned above are found in the As contents in wheat $(-71 \%)$ and maize $(+71 \%)$. However, these only lead to a relatively small reduction in the $\mathrm{CL}(\mathrm{As})_{\mathrm{eco}}(-0.5$ to $+2.9 \%)$. The deviation of the zinc content for wheat $(+65 \%)$ and maize $(+47 \%)$ would lead to an increase of $\mathrm{CL}(\mathrm{Zn})_{\text {eco }}$ by $57 \%$ and $46 \%$, respectively. For copper, the use of the older content data would lead to a reduction of $\mathrm{CL}(\mathrm{Cu})_{\text {eco }}$ (Table 24$)$.

\section{Crop rotations}

The assumption of ideal-typical crop rotations according good professional practice in agriculture does not currently correspond to the practice everywhere in Germany. Currently, more silage maize and wheat are cultivated than is needed to ensure sustainable soil fertility. 


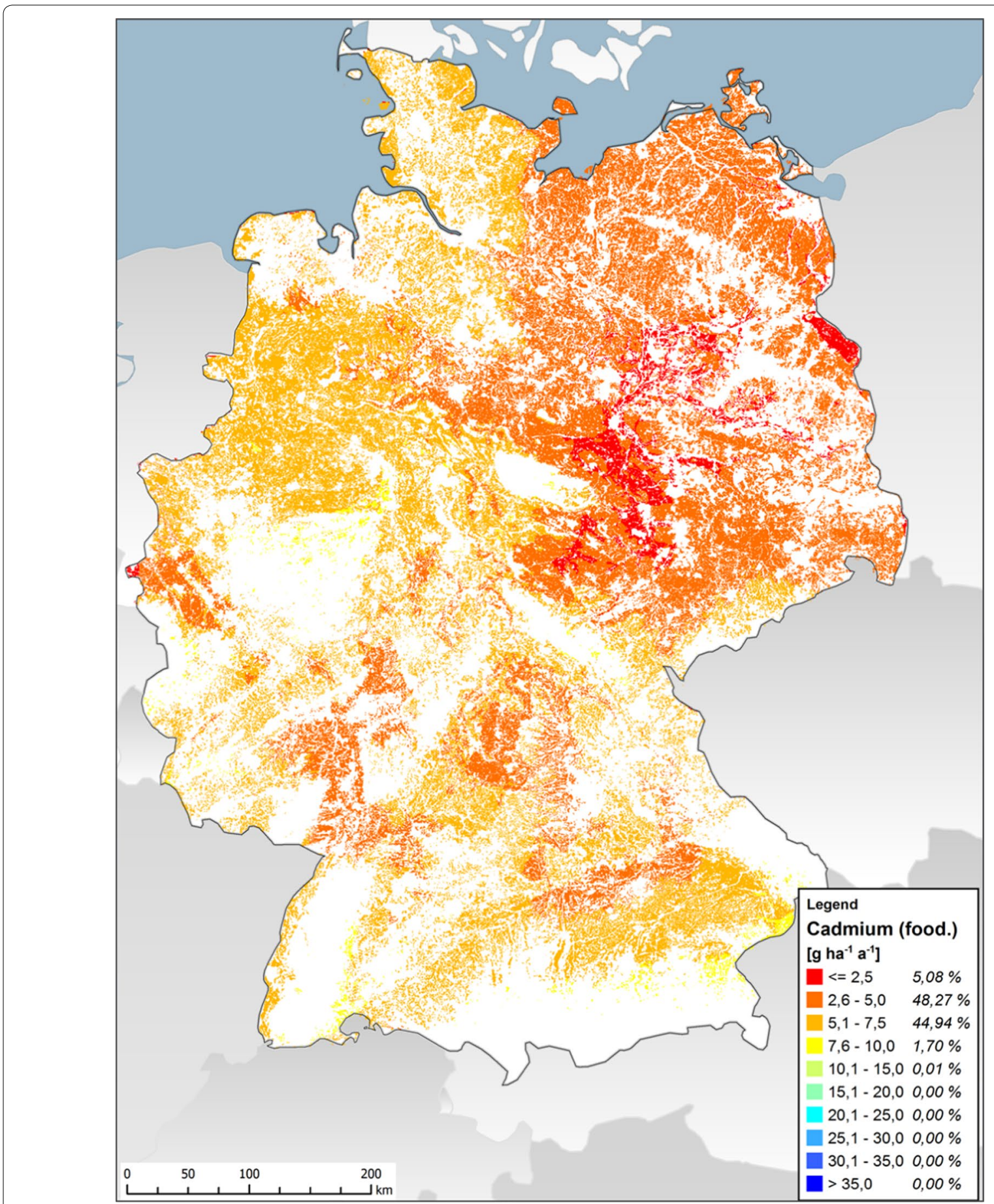

Fig. 2 Critical load for cadmium to protect human health when consuming wheat products in the case of a nationwide monoculture with wheat on arable land in Germany

The worst case can be a monoculture with silage maize or a monoculture with wheat (Figs. 1, 2).

There is a slight increase in the critical loads for the "monoculture maize" variant, but a significant decrease in the critical loads for the "monoculture wheat" variant, both for the ecosystems protected and for drinking water protection (Fig. 1). The comparison of the area shares in the critical load classes $\mathrm{CL}(\mathrm{Cd})_{\text {food }}$ shows a clear shift to the more sensitive classes for monoculture wheat (Fig. 3). 

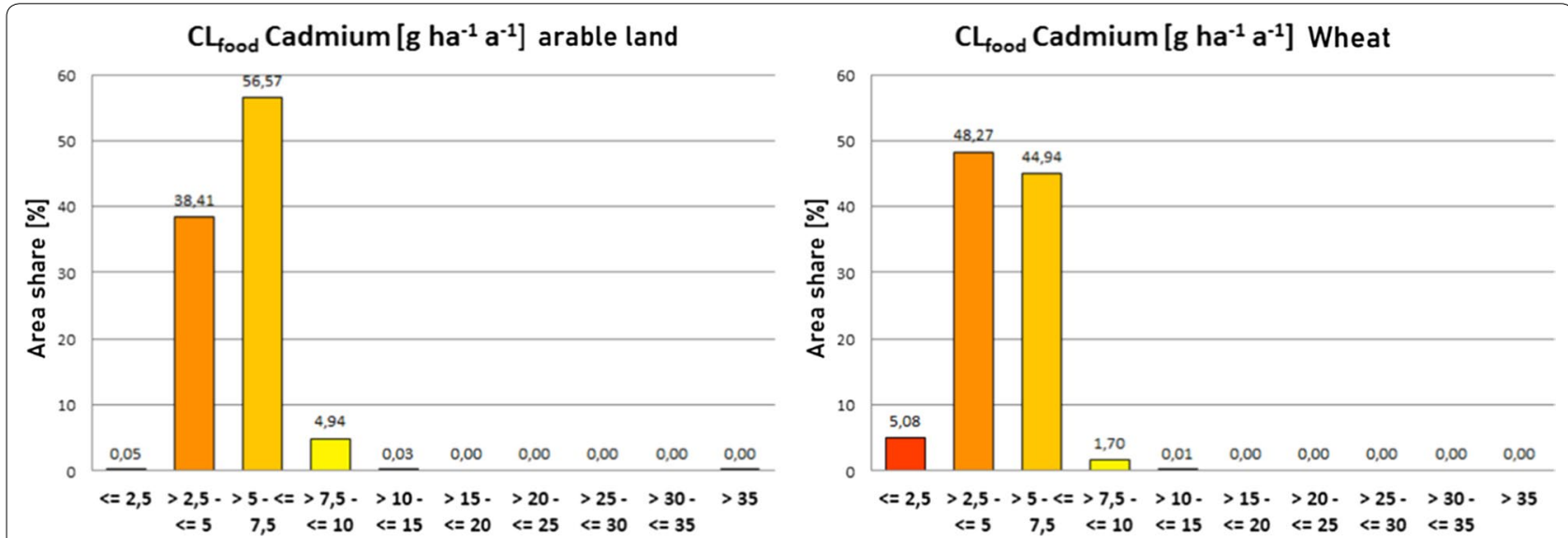

Fig. 3 Comparison of the proportions of arable land in Germany in the classes of critical load for cadmium for human health $\left(C L(C d)_{\text {food, }}\right.$ in the variant "crop rotation according to good professional practice" (left), "monoculture wheat" (right)

Table 25 Sensitivity analysis using an example calculation for $\mathrm{CL}(\mathrm{M})_{\text {drink }}$ with different leaching rates and otherwise the same input data at a field site with cambisol vega from clayey-loamy sediments and at a forest site with sandcambisol in the subcontinental climate zone of Brandenburg

\begin{tabular}{|c|c|c|c|c|c|c|c|c|}
\hline & & $\begin{array}{l}\text { Seepage rate } \\
\mathrm{mm} \mathrm{a}^{-1}\end{array}$ & $\begin{array}{l}\mathrm{CL}(\mathrm{Pb})_{\text {drink }} \\
\mathrm{g} \mathrm{ha}^{-1} \mathrm{a}^{-1}\end{array}$ & $\mathrm{CL}(\mathrm{Cd})_{\text {drink }}$ & $\mathrm{CL}(\mathrm{Hg})_{\text {drink }}$ & $\mathrm{CL}(\mathrm{As})_{\text {drink }}$ & $\mathrm{CL}(\mathrm{Cu})_{\text {drink }}$ & $\mathrm{CL}(\mathrm{Cr})_{\text {drink }}$ \\
\hline \multirow[t]{4}{*}{ Input data and results used in this paper } & Wheat & $66.0^{\mathrm{a}}$ & 6.8 & 2.2 & 0.05 & 6.9 & 1357.0 & 36.9 \\
\hline & Silage maize & $66.0^{\mathrm{a}}$ & 15.8 & 3.8 & 0.93 & 8.2 & 1481.0 & 66.6 \\
\hline & Meadow & $66.0^{\mathrm{a}}$ & 14.2 & 3.0 & 0.24 & 7.4 & 1367.4 & 36.0 \\
\hline & Pine & $66.0^{\mathrm{a}}$ & 9.6 & 4.2 & 0.06 & 6.6 & 1322.5 & 33.6 \\
\hline \multirow[t]{4}{*}{ Alternative input data and results } & Wheat & $111.0^{\mathrm{b}}$ & 11.3 & 3.6 & 0.05 & 11.4 & 2257.0 & 59.4 \\
\hline & Silage maize & $111.0^{\mathrm{b}}$ & 20.3 & 5.2 & 0.93 & 12.7 & 2381.0 & 89.1 \\
\hline & Meadow & $111.0^{\mathrm{b}}$ & 18.7 & 4.3 & 0.25 & 11.9 & 2267.4 & 58.5 \\
\hline & Pine & $111.0^{\mathrm{b}}$ & 14.1 & 5.6 & 0.08 & 11.1 & 2222.5 & 56.1 \\
\hline \multirow[t]{4}{*}{ Deviations [\%] } & Wheat & 68.2 & 65.8 & 60.8 & 64 & 60.8 & 67.0 & 29.1 \\
\hline & Silage maize & 68.2 & 28.5 & 35.3 & 28 & 40.2 & 61.7 & 7.9 \\
\hline & Meadow & 68.2 & 33.2 & 47.2 & 51 & 61.1 & 67.0 & 30.0 \\
\hline & Pine & 68.2 & 46.8 & 31.8 & 65 & 68.0 & 68.1 & 66.9 \\
\hline
\end{tabular}

a According to BGR [21] (2014)

b According to MUGV [62]

\section{Leaching rate}

The comparison of leaching rates according to BGR [25] with corresponding larger-scale surveys on groundwater recharge in the north-eastern German lowlands shows large discrepancies. For example, an average seepage rate of $66 \mathrm{~mm} \mathrm{a}^{-1}$ according to BGR for Brandenburg is offset by an average seepage rate of $111 \mathrm{~mm} \mathrm{a}^{-1}$ according to a publication of the Brandenburg Ministry for the Environment, Health and Consumer Protection [62]. For SaxonyAnhalt, too, the data differ from an average of $56 \mathrm{~mm} \mathrm{a}^{-1}$ [25] to an average of $90 \mathrm{~mm} \mathrm{a}^{-1}$ [63]. Even if the regional data are obviously not yet based on the 30-year average
1981-2010, as in the case of the BGR map, such large deviations cannot result from the temporal offset.

The seepage rate has a significant influence on the result of the critical load calculation (Table 25).

The percentage deviation of the leaching rate, assuming otherwise the same input values, is reflected at most in the same percentage deviation of the $\mathrm{CL}(\mathrm{M})_{\mathrm{drink}}$ for wheat and pine as well as for all receptors with respect to copper. The $\mathrm{CL}(\mathrm{Cr})_{\text {drink }}$ has the smallest deviation.

\section{Heavy metal concentration in leachate}

The critical concentrations of metals in leachate used in this study to calculate critical loads for ecosystem 
Table 26 Comparison of insignificance threshold values for the metal concentration in leachate [65] with the critical total concentrations in leachate used in this study

\begin{tabular}{|c|c|c|c|c|c|}
\hline & \multicolumn{3}{|c|}{ Critical concentration used } & \multicolumn{2}{|l|}{ Insignificance thresholds ${ }^{e}$} \\
\hline & \multicolumn{2}{|c|}{ Ecosystem protection } & \multirow{2}{*}{$\begin{array}{l}\text { Drinking water } \\
\text { protection }^{\mathrm{h}}\end{array}$} & \multicolumn{2}{|c|}{ Ecosystem and drinking water protection } \\
\hline & & $\mu \mathrm{g} \mathrm{I}^{-1}$ & & & $\mu \mathrm{gl}^{-1}$ \\
\hline As & PNEC & $70^{\mathrm{a}}$ & 10 & Base value $^{f}$ & 3.2 \\
\hline $\mathrm{Cr}(\| I I)$ & NOEC & $44^{\mathrm{b}}$ & 50 & Ecotoxicological impact threshold ${ }^{f}$ & 3.4 \\
\hline $\mathrm{Cu}$ & PNEC & $1-50^{c}$ & 2000 & Base value ${ }^{g}$ & 5.4 \\
\hline $\mathrm{Ni}$ & NOEC & $25-700^{c}$ & - & Base value ${ }^{g}$ & 7 \\
\hline $\mathrm{Zn}$ & NOEC & $20-90^{c}$ & - & Base value ${ }^{g}$ & 60 \\
\hline $\mathrm{Pb}$ & NOEC & $0.08-71.5^{c}$ & 10 & Ecotoxicological impact threshold ${ }^{f}$ & 1.2 \\
\hline $\mathrm{Cd}$ & NOEC & $0.43-7.16^{c}$ & 3 & Base value ${ }^{g}$ & 0.3 \\
\hline $\mathrm{Hg}$ & NOEC & $0.058-17.4^{c}$ & 1 & Base value ${ }^{g}$ & 0.1 \\
\hline \multicolumn{6}{|c|}{ a Doyle et al. [50] in Reinds et al. [33] } \\
\hline \multicolumn{6}{|c|}{ b Crommentuijn et al. [96] in Reinds et al. [33] } \\
\hline \multicolumn{6}{|c|}{ ¿ WHAM modeling results [97] } \\
\hline \multicolumn{6}{|c|}{ d Reinds et al. [33] } \\
\hline \multicolumn{6}{|c|}{ e Zeddel et al. [65] } \\
\hline \multicolumn{6}{|c|}{ f Ecotoxicological impact threshold < human toxicological impact threshold } \\
\hline \multicolumn{6}{|c|}{9 The lower value based on ecotoxicity was below the base value, so that the JRC is reported at the level of the base value } \\
\hline \multicolumn{6}{|c|}{ h Drinking Water Ordinance for Germany [38] } \\
\hline \multicolumn{6}{|c|}{$\begin{array}{l}\text { i Predicted no-effect concentration }=\text { the predicted concentration of a substance that is normally dangerous to the environment and up to which no effects on the } \\
\text { environment are observed }\end{array}$} \\
\hline
\end{tabular}

protection correspond to the specifications of Reinds et al. [33]. Accordingly, the critical total concentrations for copper, nickel, zinc, lead and cadmium were calculated model-based according to their bioavailability depending on the soil-specific $\mathrm{pH}$ value and the content of organic mass and dissolved organic carbon [18, 29, 30]. The modelling is based on PNEC values (for As and $\mathrm{Cu}$ ) and NOEC values (for $\mathrm{Cr}, \mathrm{Ni}, \mathrm{Zn}, \mathrm{Pb}, \mathrm{Cd}$ and $\mathrm{Hg}$ ). From the soil-specific modelling on the basis of the reference profiles of the $B U ̈ K 1000 \mathrm{~N}$, value ranges of the total concentration result for $\mathrm{Cu}, \mathrm{Ni}, \mathrm{Zn}, \mathrm{Pb}, \mathrm{Cd}$ and $\mathrm{Hg}$ (Table 26).

A joint working group with representatives of LAWA, ${ }^{5}$ $\mathrm{LABO}^{6}$ and $\mathrm{LAGA}^{7}$ updated the report "Derivation of Insignificance Thresholds for Groundwater" [64] from 2013 to 2015 and prepared the corresponding amendments and the reformulation of a chapter "Principles for the Application of Insignificance Thresholds" [65]. The comparison of low-minimity threshold values for the metal concentration in leachate [65] with the critical total

\footnotetext{
${ }^{5}$ Working Group of the Federal States for Water protection.

${ }^{6}$ Working Group of the Federal States for Soil protection.

7 Working Group of the Federal States for Waste Recovery.
}

concentrations in leachate used in this paper is shown in Table 28.

The low thresholds for copper, zinc, lead and mercury lie within the respective ranges of the soil-specific modelled results for ecosystem protection. However, the lowest thresholds for arsenic, chromium, nickel and cadmium are below the critical concentrations used to calculate the critical loads in this paper. The largest differences are for arsenic, chromium and nickel, so that the critical loads result in deviations in the result of up to $-95 \%$ when using the low-value thresholds as input values in the calculation as an alternative (Table 27).

The percentage deviation of the critical limits in the case of alternative use of the lowest thresholds according to Zeddel et al. [65] is reflected in an almost equally high percentage deviation of the $\mathrm{CL}(\mathrm{M})_{\mathrm{eco}}$.

\section{$p H$}

In the $\mathrm{pH}$ range considered in Table 28, higher $\mathrm{pH}$ values result in lower critical loads. The $\mathrm{pH}$ values used in the determination of the $\mathrm{pH}$-dependent critical limits and thus in the calculation of the $\mathrm{CL}(\mathrm{M})_{\text {eco }}$ were derived from the classes of the acidity per horizon of the BÜK1000N soil profiles. These are average values for the typical soil types in Germany under the respective use. Since 
Table 27 Sensitivity analysis using an example calculation for $\mathrm{CL}(\mathrm{M})_{\text {eco }}$ with different critical total concentrations in leachate and otherwise the same input data at an arable site with cambisol vega from clayey loamy fluviatile sediments in the sub-Atlantic climate zone and at a forest site with sandy cambisol in the subcontinental climate zone

\begin{tabular}{|c|c|c|c|c|c|c|c|}
\hline & & \multicolumn{3}{|c|}{$\begin{array}{l}\text { Metal concentration in leachate } \\
\left(\mu \mathrm{g} \mathrm{I}^{-1}\right)\end{array}$} & \multicolumn{3}{|c|}{$\begin{array}{l}\text { Critical loads ecosystem protection } \\
\left(\mathrm{g} \mathrm{ha}^{-1} \mathrm{a}^{-1}\right)\end{array}$} \\
\hline & & {$[A s]_{\text {crit }}$} & {$[\mathrm{Cr}]_{\text {crit }}$} & {$[\mathrm{Ni}]_{\text {crit }}$} & $\mathrm{CL}(\mathrm{As})_{\mathrm{eco}}$ & $\mathrm{CL}(\mathrm{Cr})_{\text {eco }}$ & $\mathrm{CL}(\mathrm{Ni})_{\text {eco }}$ \\
\hline \multirow[t]{4}{*}{ Input data and results used in this paper } & Wheat & 70.0 & 44.0 & 106.8 & 205.6 & 132.9 & 315.0 \\
\hline & Silage maize & 70.0 & 44.0 & 106.8 & 206.9 & 162.6 & 339.8 \\
\hline & Meadow & 70.0 & 44.0 & 106.8 & 206.1 & 132.1 & 320.1 \\
\hline & Pine & 70.0 & 44.0 & 197.9 & 46.2 & 29.7 & 133.9 \\
\hline \multirow{4}{*}{$\begin{array}{l}\text { Alternative input data (here: minority thresholds } \\
\text { according to Zeddel et al. [65] and results }\end{array}$} & Wheat & 3.2 & 3.4 & 7.0 & 9.7 & 13.8 & 22.4 \\
\hline & Silage maize & 3.2 & 3.4 & 7.0 & 11.0 & 43.6 & 47.2 \\
\hline & Meadow & 3.2 & 3.4 & 7.0 & 10.1 & 13.0 & 27.5 \\
\hline & Pine & 3.2 & 3.4 & 7.0 & 2.1 & 2.9 & 7.9 \\
\hline \multirow[t]{4}{*}{ Deviations [\%] } & Wheat & -95.4 & -92.3 & -93.4 & -95.3 & -89.6 & -92.9 \\
\hline & Silage maize & -95.4 & -92.3 & -93.4 & -94.7 & -73.2 & -86.1 \\
\hline & Meadow & -95.4 & -92.3 & -93.4 & -95.1 & -90.2 & -91.4 \\
\hline & Pine & -95.4 & -92.3 & -96.5 & -95.4 & -90.3 & -94.1 \\
\hline
\end{tabular}

Table 28 Sensitivity analysis based on an example calculation for $\mathrm{CL}(\mathrm{M})_{\mathrm{eco}}$ with different pH values and otherwise the same input data at a forest site with sand-cambisol in the Atlantic climate zone of northwest Germany

\begin{tabular}{|c|c|c|c|c|c|c|}
\hline & \multicolumn{2}{|c|}{ Low $\mathrm{pH}$} & \multicolumn{2}{|c|}{ High pH } & \multicolumn{2}{|c|}{ Deviation [\%] } \\
\hline & Beech & Pine & Beech & Pine & Beech & Pine \\
\hline Soil & \multicolumn{2}{|c|}{ Cambisol from nutrient-poor sands } & \multicolumn{2}{|c|}{ Cambisol from nutrient-rich sands } & & \\
\hline $\mathrm{pH}[-]$ & 4.1 & 4.1 & 4.9 & 4.9 & 19.9 & 19.9 \\
\hline Yield [t dry mass ha $\left.{ }^{-1} \mathrm{a}^{-1}\right]$ & 4.4 & 1.7 & 4.7 & 1.9 & 5.7 & 7.7 \\
\hline $\mathrm{CL}(\mathrm{Pb})_{\mathrm{eco}}\left[\mathrm{g} \mathrm{ha} \mathrm{a}^{-1} \mathrm{a}^{-1}\right]$ & 41.7 & 30.7 & 13.4 & 8.2 & -67.9 & -73.2 \\
\hline $\mathrm{CL}(\mathrm{Cd})_{\mathrm{eco}}\left[\mathrm{g} \mathrm{ha} \mathrm{h}^{-1} \mathrm{a}^{-1}\right]$ & 9.1 & 9.0 & 5.4 & 6.2 & -40.9 & -31.4 \\
\hline $\mathrm{CL}(\mathrm{Ni})_{\text {eco }}\left[\mathrm{g} \mathrm{ha}^{-1} \mathrm{a}^{-1}\right]$ & 586.1 & 462.0 & 268.2 & 210.6 & -54.2 & -54.4 \\
\hline $\mathrm{CL}(\mathrm{Zn})_{\mathrm{eco}}\left[\mathrm{g} \mathrm{ha} \mathrm{a}^{-1} \mathrm{a}^{-1}\right]$ & 213.1 & 174.8 & 153.4 & 128.9 & -28.0 & -26.3 \\
\hline $\mathrm{CL}(\mathrm{Cu})_{\text {eco }}\left[\mathrm{g} \mathrm{ha} \mathrm{h}^{-1} \mathrm{a}^{-1}\right]$ & 32.0 & 21.3 & 12.5 & 5.8 & -60.9 & -73.0 \\
\hline
\end{tabular}

a large number of input parameters are included in the WHAM modelling of the critical limits in addition to the $\mathrm{pH}$ value, soil profiles had to be sought for the sensitivity analysis with regard to the $\mathrm{pH}$ value in order to compare soil profiles in which all other input data (seepage rate, $\mathrm{OM}, \mathrm{DOM}, \mathrm{DOC}$ contents, $\mathrm{pCO}_{2}$ ) are the same and only the depth-stage-weighted mean value of the $\mathrm{pH}$ value deviates. However, the yields are not identical in a low-base and a base-rich soil according to the calculation of the yield potentials on which this report is based. Although a higher yield tends to result in higher critical load, the opposite influence of $\mathrm{pH}$ on the critical load far outweighs the effect (Table 28).

Although the $\mathrm{pH}$ value differs by only approx. $20 \%$ and at the same time the yield variations tend to have a compensating effect, the $\mathrm{CL}(\mathrm{M})_{\text {eco }}$ deviates between 26 and 73\%. Implausible $\mathrm{pH}$ values can be seen in some conductive soil profiles under forest. For example, for stagnic chernozems from loess over clay and marl rocks under forest in the top $30 \mathrm{~cm}$ of the mineral soil, the contents of exchangeable cations result in a base saturation of $7.1 \%$, which corresponds to a $\mathrm{pH}$ value of 3.2 . This seems much too low for this soil form. In raised bogs, the high contents of $\mathrm{Ca}$ and $\mathrm{Mg}$ result in a base saturation of $100 \%$ and a $\mathrm{pH}$ value of 6.8 . This cannot be explained for raised bogs. Implausible values for 4 of the above-mentioned reference soil profiles were therefore not included in the CL calculation, but replaced by expert estimates. This, however, creates some uncertainty.

\section{Organic matter content}

The organic matter content was derived from the humus class for the horizons of the guide soil profiles of the BÜK1000N. An exemplary comparison of the CL 
Table 29 Sensitivity analysis using an example calculation for $\mathrm{CL}(\mathrm{M})_{\text {eco }}$ with different organic mass contents and otherwise the same input data at grassland sites with boulder clay in the subcontinental climate zone of Northeast Germany

\begin{tabular}{llll}
\hline $\begin{array}{l}\text { Vegetation } \\
\text { Soil }\end{array}$ & $\begin{array}{l}\text { Weed } \\
\text { Luvic arenosols } \\
\text { from boulder } \\
\text { clay }\end{array}$ & $\begin{array}{l}\text { Weed } \\
\text { Distric gley } \\
\text { from boulder } \\
\text { clay }\end{array}$ & $\begin{array}{l}\text { Deviations } \\
{[\%]}\end{array}$ \\
\hline $\mathrm{OM}[\mathrm{mass} \%]$ & 1 & 15 & -93.3 \\
$\mathrm{CL}(\mathrm{Pb})_{\text {eco }}\left[\mathrm{g} \mathrm{ha}^{-1} \mathrm{a}^{-1}\right]$ & 13.0 & 14.8 & -12.2 \\
$\mathrm{CL}(\mathrm{Cd})_{\text {eco }}\left[\mathrm{g} \mathrm{ha}^{-1} \mathrm{a}^{-1}\right]$ & 5.3 & 5.5 & -3.6 \\
$\mathrm{CL}(\mathrm{Hg})_{\text {eco }}\left[\mathrm{g} \mathrm{ha}^{-1} \mathrm{a}^{-1}\right]$ & 0.22 & 0.22 & -2.2 \\
$\mathrm{CL}(\mathrm{Ni})_{\text {eco }}\left[\mathrm{g} \mathrm{ha}^{-1} \mathrm{a}^{-1}\right]$ & 273.3 & 280.8 & -2.7 \\
$\mathrm{CL}(\mathrm{Zn})_{\text {eco }}\left[\mathrm{g} \mathrm{ha}^{-1} \mathrm{a}^{-1}\right]$ & 358.9 & 370.1 & -3.0 \\
$\mathrm{CL}(\mathrm{Cu})_{\text {eco }}\left[\mathrm{g} \mathrm{ha}^{-1} \mathrm{a}^{-1}\right]$ & 36.7 & 46.4 & -20.9 \\
\hline
\end{tabular}

results therefore requires the comparison of two leading soil profiles with clearly differing humus classes and otherwise the same parameter values as occur on soils of the same soil form group under grassland use (Table 29).

The effects of a high deviation of the OM content of $93 \%$ only have a dampened effect on the respective critical load. The maximum deviation of the $\mathrm{CL}(\mathrm{Cu})_{\text {eco }}$ is $21 \%$. When deriving the OM contents from the humus classes, no implausibilities were noticed.

\section{Dissolved organic matter and dissolved organic carbon content}

The values for deciduous and coniferous forest used in this study are taken from De Vries et al. [46]. In the manual of the ICP Modeling and Mapping [18, 29, 30],
Chapter 5.5 only one value is given for forest in general. Kalbitz et al. [66] published results of a field study at 23 reference sites with spruce stands. The DOC average over the $\mathrm{O}$ horizons is therefore $41.3 \mathrm{mg} \mathrm{l}^{-1}$. These data from German forests fit very well with the Dutch data for coniferous forests [46]. Their range is from approx. $22-83 \mathrm{mg} \mathrm{l}^{-1}$. The manual points out that the number of investigated sites is not yet sufficient to derive generalisations for reliable reference values. This parameter is still subject to a very high degree of uncertainty. Therefore, Table 30 shows the results with the variants according to De Vries et al. [46] and according to Manual [30], as well as with a fictitious extremely low value and an extremely high value. Since mercury largely occurs only in the organic layer, the $\mathrm{CL}(\mathrm{Hg})_{\text {eco }}$ is particularly sensitive to the DOC/DOM content compared to the other metals (Manual: Table 5.21).

The deviations of the $\mathrm{CL}(\mathrm{Hg})_{\text {eco }}$ results for extreme variants from the results of this study are very high (maximum 131\%). However, the deviation of the results with the variants according to De Vries et al. [46] and according to Manual $[18,29,30]$ is only small (maximum: $-10 \%)$.

The multi-factorial influence of $\mathrm{pH}$ and $\mathrm{DOC}$ on the variability of the critical load is shown in Table 31.

\section{Exceeding critical loads}

After completion of the investigations described in Additional file 2, it became known that the emission data for the years considered were updated as the basis for the deposition modelling by TNO and EMEP for the years considered and that new concentration and deposition data are now available from EMEP in $0.1^{\circ} \mathrm{x} 0.1^{\circ}$ resolution, at least for $\mathrm{Pb}, \mathrm{Cd}, \mathrm{Hg}$. As soon as these are available and other prerequisites for the recalculation of

Table 30 Sensitivity analysis using an example calculation for $\mathrm{CL}(\mathrm{Hg})_{\text {eco }}$ with different contents of dissolved organic mass and otherwise the same input data at a coniferous forest and a deciduous forest site with boulder clay in the subcontinental climate zone of north-eastern Germany

\begin{tabular}{|c|c|c|c|c|}
\hline & & $\mathrm{DOC}$ & $\mathrm{CL}(\mathrm{Hg})_{\text {eco }}$ & $\begin{array}{l}\text { Deviation } \\
\mathrm{CL}(\mathrm{Hg})_{\text {eco }} \\
\%\end{array}$ \\
\hline & & & & \\
\hline \multirow[t]{2}{*}{ Input data and results in this study ${ }^{a}$} & Beech & 32 & 0.2288 & \\
\hline & Pine & 40 & 0.1736 & \\
\hline \multirow[t]{2}{*}{ Input data according to Manual ${ }^{b}$} & Beech & 35 & 0.2420 & 6 \\
\hline & Pine & 35 & 0.1562 & -10 \\
\hline \multirow{4}{*}{$\begin{array}{l}\text { Alternative input data and results from fictitious } \\
\text { assumptions of extremes }\end{array}$} & Beech & 1 & 0.0924 & -60 \\
\hline & Pine & 1 & 0.0380 & -78 \\
\hline & Beech & 100 & 0.5279 & 131 \\
\hline & Pine & 100 & 0.3822 & 120 \\
\hline
\end{tabular}

Sources: ${ }^{a}$ deVries et al. [46]. ${ }^{b}$ Manual of the ICP Modeling and Mapping [18, 29, 30]: Chapter V.5) 
Table 31 Sensitivity analysis using an example calculation for $\mathrm{CL}(\mathrm{Cd})_{\text {eco }}$ and $\mathrm{CL}(\mathrm{Pb})_{\text {eco }}$ with different $\mathrm{pH}$ and dissolved organic mass contents and otherwise identical input data at a coniferous forest and a deciduous forest site with rendzic leptosol from marl in the subcontinental climate zone of north-eastern Germany

\begin{tabular}{|c|c|c|c|c|c|c|c|}
\hline & & DOC & $\mathrm{pH}$ & $\mathrm{CL}(\mathrm{Cd})_{\text {eco }}$ & $\mathrm{CL}(\mathrm{Pb})_{\text {eco }}$ & $\begin{array}{l}\text { Deviations } \\
\mathrm{CL}(\mathrm{Cd})_{\text {eco }}\end{array}$ & $\begin{array}{l}\text { Deviations } \\
\mathrm{CL}(\mathrm{Pb})_{\text {eco }}\end{array}$ \\
\hline & & & - & & $\mathrm{gha}^{-1} \mathrm{a}^{-1}$ & & \\
\hline \multirow[t]{2}{*}{ DOC data and results in this study ${ }^{\mathrm{a}}$} & Beech & 32 & 4.0 & 8.97 & 42.7 & & \\
\hline & Pine & 40 & 4.0 & 8.89 & 31.8 & & \\
\hline \multirow[t]{2}{*}{ DOC according to Manual ${ }^{b}$} & Beech & 35 & 4.0 & 8.97 & 42.7 & 0 & 0 \\
\hline & Pine & 35 & 4.0 & 8.83 & 31.5 & -1 & -1 \\
\hline \multirow{4}{*}{$\begin{array}{l}\text { alternative input data and results from ficti- } \\
\text { tious assumptions of extremes }\end{array}$} & Beech & 1 & 4.0 & 8.84 & 40.1 & -1 & -6 \\
\hline & Pine & 1 & 4.0 & 8.73 & 29.5 & -2 & -7 \\
\hline & Beech & 100 & 4.0 & 9.28 & 48.5 & 3 & 14 \\
\hline & Pine & 100 & 4.0 & 9.07 & 36.0 & 2 & 14 \\
\hline \multirow[t]{2}{*}{ DOC data and results used in this study ${ }^{a}$} & Beech & 32 & 7.0 & 9.03 & 26.0 & & \\
\hline & Pine & 40 & 7.0 & 9.73 & 21.6 & & \\
\hline \multirow[t]{2}{*}{ DOC according to Manual ${ }^{b}$} & Beech & 35 & 7.0 & 9.08 & 26.0 & 0 & 0 \\
\hline & Pine & 35 & 7.0 & 8.91 & 18.3 & -8 & -15 \\
\hline \multirow{4}{*}{$\begin{array}{l}\text { Alternative input data and results from ficti- } \\
\text { tious assumptions of extremes }\end{array}$} & Beech & 1 & 7.0 & 1.92 & 7.5 & -79 & -71 \\
\hline & Pine & 1 & 7.0 & 3.26 & 3.7 & -67 & -83 \\
\hline & Beech & 100 & 7.0 & 15.15 & 63.5 & 68 & 144 \\
\hline & Pine & 100 & 7.0 & 13.71 & 47.9 & 41 & 121 \\
\hline
\end{tabular}

a According to De Vries et al. [46]

b According to ICP Modeling and Mapping Manual [18, 29, 30]: Chapter 5.5)

Table 32 Maximum possible deviations of the input values in Germany and the resulting maximum possible deviations of the critical loads

\begin{tabular}{|c|c|c|c|c|}
\hline & $\begin{array}{l}\text { Possible deviation of the input } \\
\text { value from the } C L \text { input value } \\
\text { of this operation [\%]. }\end{array}$ & $\begin{array}{l}\text { Maximum possible deviation } \\
\text { of the varying } \mathrm{CL} \text { from the } \mathrm{CL} \\
\text { of this work [\%]. }\end{array}$ & $\begin{array}{l}\text { Quotient } \\
\text { from Columns } 2 \\
\text { and } 3\end{array}$ & $\begin{array}{l}\text { CL with the greatest possible } \\
\text { deviation }\end{array}$ \\
\hline (1) & (2) & (3) & (4) & (5) \\
\hline Yield & 28 & 5.9 & 0.2 & $\begin{array}{l}\mathrm{CL}(\mathrm{Cu})_{\text {eco }} \text { for podzol from weak } \\
\text { loamy sands }\end{array}$ \\
\hline $\begin{array}{l}\text { Metal content } \\
\text { in harvested } \\
\text { crop }\end{array}$ & 300 & 169 & 0.6 & $\mathrm{CL}(\mathrm{Pb})_{\mathrm{eco}}$ on silage maize fields \\
\hline Leachate rate & 68 & 68 & 1.0 & $\begin{array}{l}\mathrm{CL}(\mathrm{As})_{\text {drink }} \text { and } \mathrm{CL}(\mathrm{Cu})_{\text {drink }} \text { for pine } \\
\text { forest in Brandenburg }\end{array}$ \\
\hline Critical limit & 96.5 & 94.1 & 1.0 & $\mathrm{CL}(\mathrm{Ni})_{\mathrm{eco}}$ for pine \\
\hline $\mathrm{pH}$ & 19.9 & -73 & -3.7 & $\mathrm{CL}(\mathrm{Pb})_{\mathrm{eco}}, \mathrm{CL}(\mathrm{Cu})_{\mathrm{eco}}$ for pine forests \\
\hline OM content & -93 & -21 & 0.2 & $\mathrm{CL}(\mathrm{Cu})_{\text {eco }}$ for grassland \\
\hline
\end{tabular}

critical load exceedances based on them are fulfilled, the results presented in Additional file 2 could be updated accordingly.

\section{Discussion}

The random sensitivity calculations were designed in such a way that the possible range of deviations of the input data used in this study for CL determination from alternative values is reflected (Table 32).
Table 32 shows that even minor positive $\mathrm{pH}$ deviations have the greatest negative effects on critical loads. The $\mathrm{pH}$ value is therefore the input parameter to which all critical loads react most sensitively. However, the $\mathrm{pH}$ values, as used in this study for the CL calculation, are derived from the BÜK1000N database [21] from nationwide measurement campaigns, i.e. representative of the typical soil forms in Germany and also quality-checked and one of the sources with the lowest uncertainties. In a 
restrictive manner, reference must be made to the 8 reference profiles of a total of 675 profiles in the BÜK database, for which the $\mathrm{pH}$ values do not appear plausible from our expert point of view.

The largest deviations in the input data were found for the metal contents in the biomass to be harvested. However, the influence of this deviation on the respective $\mathrm{CL}(\mathrm{M})$ is damped. Negatively deviating OM contents also have a reducing effect on $\mathrm{CL}$, but less drastically than the $\mathrm{pH}$ value. However, no data on OM contents could be found in the literature in addition to the BÜK1000N database used here, so that a comparison with values from other sources was not possible. For this parameter, too, it can be estimated that the BÜK1000N values used in this paper are based on a reliable database.

For all other input values, a comparison with other literature references shows that the values used here for the CL calculation are below the span or in the lower half of the value ranges of other data sources. Thus, this study results in conservative critical loads based on conservatively estimated leachate rates, metal contents in the harvested crop and DOC contents in the soil. The input values used or derived from the BÜK1000N (yield potential, $\mathrm{pH}$ values, OM contents) are to be evaluated as robust. The leachate rates according to BGR [25] are also quality-tested. There are major uncertainties in the determination of DOC contents, which are recommended by [46] (Manual of ICP Modeling and Mapping [18, 29, 30], but for which validation is still required.

The total critical concentrations of lead, cadmium and mercury used are based on NOEC values for plants, invertebrates and soil microorganisms and are therefore based on thresholds for terrestrial ecosystems. The threshold values for the concentration of copper, nickel and zinc have been determined on the basis of NOEC and PNEC values of soil water organisms. In this respect, it has yet to be proven that plants are no more sensitive than the microorganisms in soil water. The critical threshold values for arsenic and chromium have been transferred from NOEC or PNEC values of aquatic organisms to terrestrial ecosystems. For these two metals, therefore, the greatest uncertainties remain. From the latest ecotoxicological studies on organisms in leachate, minor threshold values were derived [65], which for chromium and arsenic are far below the PNEC and NOEC values documented in Reinds et al. [33].

The critical loads maps offer a Germany-wide overview of the sensitivity of the receptor surfaces on a scale of 1:1 million. In particular, they enable a comparison with the current entries for a Germany-wide assessment of the risks for humans and the environment. However, they also offer a relative comparison of the sensitivity of the receptor surfaces to each other as well as the identification of regional differences in national or international evaluations. They are not suitable for large-scale or site-specific evaluation due to the small map scale.

In particular the CL data bases for lead, cadmium, mercury can be considered well validated, but also the CL for copper, nickel and zinc can be recommended for the above-mentioned small-scale applications. However, the uncertainties of the $\mathrm{CL}(\mathrm{As})_{\text {eco }}$ and $\mathrm{CL}(\mathrm{Cr})_{\text {eco }}$ cards are still considerable. Further research is required in particular with regard to the determination of ecotoxicological critical limits for arsenic and chromium.

\section{Conclusions}

A comparison of the critical loads determined for Germany with the assessment values of binding legal regulations reveals clear differences (Table 33).

The comparison shows that there are regions in Germany where the protection of drinking water is possibly not sufficiently guaranteed by the applicable assessment values. The need for protection, as shown by the critical loads $\left(\mathrm{CL}(\mathrm{M})_{\text {drink }}\right)$, is significantly higher in Brandenburg, Saxony-Anhalt and in the north-east of Saxony and Mecklenburg-Western Pomerania with regard to the input of $\mathrm{Hg}, \mathrm{Cd}, \mathrm{Pb}, \mathrm{As}$, and $\mathrm{Cr}$ into groundwater than the guarantee of protection by existing binding assessment values. Only for $\mathrm{Cu}$ and $\mathrm{Zn}$ are the assessment values of existing regulations for drinking water protection sufficient.

The protection of health during the consumption of wheat products is largely guaranteed by the assessment values for $\mathrm{Cd}$ inputs, with the exception of arable land in the Heinsberg district on the Dutch border. Here the $\mathrm{CL}(\mathrm{Cd})_{\text {food }}$ is lower than the mandatory assessment values in small areas.

The protection of ecosystems throughout Germany is possibly only guaranteed by binding assessment values for As and $\mathrm{Ni}$. The $\mathrm{CL}(\mathrm{Hg})_{\text {eco }}$ are even lower than the binding assessment values throughout Germany. For all other metals, $\mathrm{Cd}, \mathrm{Pb}, \mathrm{Cu}, \mathrm{Zn}$ and $\mathrm{Cr}$, the critical loads $\left(\mathrm{CL}(\mathrm{M})_{\text {eco }}\right)$ in some regions indicate significantly more sensitive ecosystems.

The comparison of the human toxicologically derived assessment values with the atmogenic inputs in 2013 (mercury) and 2010 (all other metals) shows that the critical loads for drinking water protection for lead and mercury are not complied with in some regions of Germany and that there could therefore be a long-term risk to human health if drinking water is consumed, provided that the mercury actually arrives in groundwater. Especially the rain poor regions of Germany (especially Brandenburg, lowlands of Saxony-Anhalt, Leipziger Bucht, Ruhr area) with forest vegetation are affected by exceedances by $\mathrm{Hg}$ - and $\mathrm{Pb}$-entries. This area proportion 
Table 33 Comparison of the assessment values of binding legal regulations and the critical loads for Germany

\begin{tabular}{|c|c|c|c|c|c|c|c|}
\hline \multirow[t]{3}{*}{ Metal } & $\begin{array}{l}\text { TA Luft } \\
\text { Tab. } 6^{\mathrm{a}}\end{array}$ & TA Luft Tab. $8^{b}$ & BBodSchVc & $\begin{array}{l}\text { 39th BImSchV }{ }^{\text {d,e }} \text { 2004/107/ } \\
\text { EG }^{\mathrm{e}} 2008 / 50 / \mathrm{EG}^{\mathrm{e}}\end{array}$ & $\mathrm{CL}(\mathrm{M})_{\text {drink }}$ & $C L(M)_{\text {food }}$ & $\mathrm{CL}(\mathrm{M})_{\text {eco }}$ \\
\hline & \multicolumn{3}{|c|}{ Emitter-related } & \multicolumn{4}{|l|}{ General load } \\
\hline & \multicolumn{7}{|c|}{$g \mathrm{ha}^{-1} \mathrm{a}^{-1}$} \\
\hline $\mathrm{Hg}$ & 4 & $11-110$ & 1.5 & & $0.3-13.8$ & & $0.1-1.1$ \\
\hline $\mathrm{Cd}$ & 7 & $9-117$ & 6 & $2.5-7$ & $0.8-42.6$ & $1.9-19.2$ & $1.5-127.6$ \\
\hline $\mathrm{Pb}$ & 365 & $675-6935$ & 400 & $250-716$ & $3-142$ & & $2-2603$ \\
\hline As & 15 & $219-4271$ & & $2.2-6$ & $2-138$ & & $15-1669$ \\
\hline $\mathrm{Ni}$ & 55 & & 100 & $10-17.4$ & & & $37-11,232$ \\
\hline $\mathrm{Cu}$ & & 300 & & & $484-27,533$ & & $7-3384$ \\
\hline $\mathrm{Zn}$ & & 1200 & & & $1234-69,133$ & & $81-2457$ \\
\hline $\mathrm{Cr}$ & & 300 & & & $12-688$ & & 78-1049 \\
\hline
\end{tabular}

may be higher, since the German CL dataset may not reflect areas where maximum deposition rates meet a very low critical load (worst case).

Although the critical loads for cadmium for drinking water protection $\mathrm{CL}(\mathrm{Cd})_{\text {drink }}$ and for the protection of human food from wheat products $\mathrm{CL}(\mathrm{Cd})_{\text {food }}$ will not be exceeded by the atmospheric depositions in 2010 in the receptor areas of the German dataset, the German dataset may not reflect smaller areas where maximum deposition rates meet a very low critical load (worst case). In these cases, the maximum atmospheric deposition in 2010 would have exceeded CL(Cd) drink and CL(Cd) food. Although no critical loads for drinking water protection could be calculated for nickel, since the BTrinkwV does not specify a limit concentration for nickel, a comparison of the 2010 entries with the recommended assessment concentrations for nickel, converted into annual input rates in the EU position paper (2000), shows an exceedance on fields and grassland in the worst case (maximum deposition meets lowest permissible input value).

If one compares the heavy metal input 2013 (mercury) or 2010 (all other metals) with the ecotoxicologically justified assessment values, the picture is the same as for the assessment values derived from human toxicology: The critical loads for ecosystem protection $\mathrm{CL}(\mathrm{M})_{\mathrm{eco}}$ are exceeded by the mercury and lead inputs in some regions of Germany (in particular Brandenburg, Leipzig Bay, Saxony-Anhalt, Ruhr area) with forest vegetation; in addition, the $\mathrm{CL}(\mathrm{Cu})_{\text {eco is }}$ exceeded by copper inputs in 2010 in the Berlin environs and in the Ruhr area (around 1\% of the receptor area). In the worst case, $\mathrm{CL}(\mathrm{Cd})_{\text {eco }}$ could be exceeded by the maximum cadmium inputs in 2010. For example, the forests of sub-continental climatic areas are exposed to potential risks (low precipitation, high evaporation rate) due to atmospheric heavy metal inputs, but also the habitat types according to Annex 1 of the Habitats Directive with restricted or prohibited use (humid and slope forests, dry and humid heaths, moors, humid high-growing shrub meadows along watercourses, etc.). The FFH-Annex-I-habitats 91D0, 91E0, 9180, 91T0, 91U0 must therefore be regarded as particularly sensitive.

However, this rough risk assessment must be discussed in the context of uncertainties and assumptions: Since the 2010 deposition data set for Germany shows higher average depositions than the 2009 and 2011 data sets, the comparison of the 2010 depositions with the assessment values tends to show unfavourable conditions and is therefore a rather conservative view. The uncertainties of the emission rates underlying atmospheric transport modelling are very high for some metals. This uncertainty is of course transferred to the calculated deposition values.

The deposition calculations by Schaap et al. [4] do not reflect any small-scale limited direct loads in the vicinity of individual emitters. This is also shown by empirically determined deposition values, some of which are significantly higher than the deposition model values. This clarifies the character of the modelled values as background deposition and explains why the plant-related assessment values of the TA Luft and the BBodSchV are not exceeded by these deposition rates. Airborne depositions represent only a fraction of the inputs compared to inputs with fertilisers and other inputs. Including all entry paths, exceedances of the critical loads and 
the permissible additional loads of the BBodSchV could occur more widely or be significantly higher, especially on fields. As with critical loads for the protection of human health, if critical loads for ecosystem protection are exceeded, the ecosystem may accumulate without damage as long as the critical limits have not yet been reached. If the critical limits are reached, an impairment of the protected property must be expected, even if only after a corresponding reaction time of the ecosystem. Particularly in the case of heavy metal inputs, it can take centuries before a visible negative change in the protected goods occurs if the critical loads are permanently exceeded. For example, soils have a very high buffering capacity against mercury inputs. Other metals such as cadmium and nickel are more mobile and accumulate proportionally to the soil content in the biomass, so that the assumptions about the uptake rates with the biomass for the critical loads calculation are very conservative, because this calculation was generally carried out with very low concentrations in the biomass (literature values).

The objectives of the EU Air Pollution Strategy, not to allow unacceptable impacts on humans and the environment by 2020 , have not yet been met by the 2010 deposition rates. For the goal of the National Biodiversity Strategy by 2015 of establishing ecosystem-based impact thresholds for pollutants that describe the impacts on biological diversity, the critical loads for the protection of ecosystems provide a very precautionary scientific basis for discussion. Since cadmium, lead and mercury are transported far in the atmosphere, both national and international measures to reduce them are necessary in addition to plant- and project-related emission limits. In the case of other metals, the focus should be on plantrelated reductions within Germany. A first step could be the mandatory measurement and reporting of actual emission levels (especially for mercury emissions) in the operation of large emitters. However, special attention must also be paid to farm inputs, especially to protect agricultural land from harmful accumulations of substances.

\section{Supplementary information}

Supplementary information accompanies this paper at https://doi. org/10.1186/s12302-020-00391-w.

Additional file 1. Figures and Tables.

Additional file 2. Exceeding critical loads.

\section{Abbreviations}

As: arsenic, here limited to $\mathrm{As}(\mathrm{V})$, the stable form in aerobic environment (humus topsoil); $\mathrm{Cd}$ : cadmium; $\mathrm{CL}(\mathrm{Cd})_{\text {food: }}$ : critical load for cadmium for the protection of arable crops (here: wheat products) as food for humans; $\mathrm{CL}(\mathrm{M})_{\text {drink: }}$ : critical load for a metal (M stands for the chemical symbol for the metal in question) to protect drinking water as a foodstuff for humans; $\mathrm{CL}(\mathrm{M})_{\text {eco }}$ : critical load for a metal (M stands for the chemical symbol for the metal under consideration) for the protection of the considered ecosystem; CLC: corine landcover; Co: cobalt; Cr: chromium, here limited to $\mathrm{Cr}(I I I)$, the stable form in the considered humus-containing topsoil horizons; $\mathrm{Cu}$ : copper; $[\mathrm{DOM}]_{\text {swd }}$ : concentration of dissolved organic matter in the soil solution of the humus layer [ $\mathrm{g} \mathrm{m}^{-3}$ ]; DWD: German Meteorological Service; ECMF: European Centre for Medium Range Weather Forecasts; EEA: European Environmental Agency; EMEP: European Monitoring and Evaluation Programme; GIS: Geographic Information System; Hg: mercury, sum of organically bound $\mathrm{Hg}$ in methyl mercury $\left(\mathrm{CH}_{3} \mathrm{Hg}^{+}\right)$and $\mathrm{Hg}$ in inorganic forms; $[\mathrm{Hg}]_{\mathrm{OM} \text { (crit) }}$ : critical limit for $\mathrm{Hg}$ relative to solid organic matter (OM) in humus layers; CLRTAP: Convention on Long-Range Transboundary Air Pollution; $[\mathrm{M}]_{\text {free,sdw(crit): }}$ critical concentration of free metal ions in the seepage water; $[\mathrm{M}]_{\text {ha }}$ : metal content in the dry matter of the crop $\left[\mathrm{mg} \mathrm{kg}^{-1} \mathrm{TS}^{-1}\right.$ or eq $\left.\mathrm{kg}^{-1} \mathrm{TS}^{-1}\right]$; $[\mathrm{M}]_{\text {sdw(crit) }}$ : critical total concentration of metals in leachate and bound to organic, inorganic and suspended particles; $\mathrm{Mle}_{\text {(crit): }}$ tolerable leaching of the metal $\mathrm{M}$ from the soil layer under consideration with exclusive consideration of vertical rivers (leachate) $\left[\mathrm{g} \mathrm{ha}^{-1} \mathrm{a}^{-1}\right.$; Mn: manganese; Mon: molybdenum; $\mathrm{M}_{\mathrm{u}}$ : net uptake of the metal M into harvestable parts of plants $\left[\mathrm{g} \mathrm{ha}^{-1} \mathrm{a}^{-1}\right]$; Ni: nickel.

\section{Acknowledgements}

We would like to thank the Federal Environment Agency for financial support and expert assistance for the study.

\section{Authors' contributions}

WS headed the investigation and drafted the manuscript. AS and TS carried out the calculations. All authors read and approved the final manuscript.

\section{Funding}

The investigation was funded by the Federal Environment Agency of Germany.

\section{Availability of data and materials}

It is planned to archive the data in a repository.

Ethics approval and consent to participate

Not applicable.

Consent for publication

Not applicable.

\section{Competing interests}

The authors declare that there are no competing interests.

\section{Author details}

1 ÖKO-DATA - Ökosystemanalyse und Umweltdatenmanagement, Lessingstraße 16, 16356 Ahrensfelde, Germany. ${ }^{2}$ Lehrstuhl für Landschaftsökologie, Universität Vechta, Postfach 1553, 49364 Vechta, Germany. ${ }^{3}$ Umweltbundesamt, Wörlitzer Platz 1, 06844 Dessau-Roßlau, Germany.

Received: 6 June 2020 Accepted: 19 August 2020

Published online: 12 January 2021

References

1. Alloway BJ (2013) Sources of Heavy Metals and Metalloids in Soils. In: Alloway BJ (ed) Heavy metals in soils. Trace metals and metalloids in soils and their bioavailability. Springer, Dordrecht, pp 11-50

2. Hou D, O'Connor D, Igalavithana AD et al (2020) Metal contamination and bioremediation of agricultural soils for food safety and sustainability. Nat Rev Earth Environ 1:366-381. https://doi.org/10.1038/s43017-020-0061-y

3. EMEP - Centres MSC-E (2015) EMEP Status Reports: Heavy Metals: Analysis of long-term trends, country-specific research and progress in mercury regional and global modelling (No 2/2015). Online im Internet: URL: http://www.msceast.org/index.php/reports Web-Adresse aufgerufen am: 20.07.2015]. Country specific information, complementary to the EMEP Status Reports: online im Internet: URL: http://www.msceast.org/index .php/emep-countries. Assessed 20 July 2015 
4. Schaap M, Hendriks C, Jonkers S, Builtjes P (2018) Assessment of the atmospheric heavy metal deposition to terrestrial ecosystems in Germany. Part 1 of: Schröder W, Nickel S, Schlutow A, Nagel H-D, Scheuschner T (2018) Auswirkungen der Schwermetall - Emissionen auf Luftqualität und Ökosysteme in Deutschland - Quellen, Transport, Eintrag, Gefährdungspotenzial [Impacts of heavy metal emission on air quality and ecosystems across Germany - Sources, transport, deposition and potential hazards]. UBA-TEXTE 107/2018:1-81

5. Schröder W, Nickel S, Schlutow A, Nagel H-D, Scheuschner T (2018) Auswirkungen der Schwermetall - Emissionen auf Luftqualität und Ökosysteme in Deutschland - Quellen, Transport, Eintrag, Gefährdungspotenzial. Teil 2: Integrative Datenanalyse, Erheblichkeitsbeurteilung und Untersuchung der gegenwärtigen Regelungen und Zielsetzungen in der Luftreinhaltung und Vergleich mit ausgewählten Anforderungen, die sich in Bezug auf den atmosphärischen Schadstoffeintrag aus den verschiedenen Rechtsbereichen ergeben [Effects of heavy metals - emissions on air quality and ecosystems in Germany - sources, transport, input, hazard potential. Part 2: Integrative data analysis, assessment of relevance and investigation of current regulations and objectives in air pollution control and comparison with selected requirements arising from the various areas of legislation with regard to atmospheric pollutant input]. UBA-Texte108/2018, pp.1-257

6. Schröder W, Nickel S, Völksen B, Dreyer A, Wosniok W (2019b) Nutzung von Bioindikationsmethoden zur Bestimmung und Regionalisierung von Schadstoffeinträgen für eine Abschätzung des atmosphärischen Beitrags zu aktuellen Belastungen von Ökosystemen [Use of bioindication methods for the determination and regionalisation of pollutant inputs to estimate the atmospheric contribution to current ecosystem pressures]. Bd. 1, pp 1-189, Bd. 2 pp. 1-296, UBA-Texte 91/2019

7. BImSchG (1974/2020) Gesetz zum Schutz vor schädlichen Umwelteinwirkungen durch Luftverunreinigungen, Geräusche, Erschütterungen und ähnliche Vorgänge (Bundes-Immissionsschutzgesetz - BImSchG) [German Federal Immission Control Act of 15 March 1974, last amended by Article 2 of the Ordinance of $1 \mathrm{G}$ of 19 June 2020]

8. Luft TA (Bundesministerium für Umwelt, Naturschutz und Reaktorsicherheit) (2002) Erste Allgemeine Verwaltungsvorschrift zum Bundes-Immissionsschutzgesetz (Technische Anleitung zur Reinhaltung der Luft - TA Luft) vom 24. Juli 2002 [First General Administrative Regulation on the Federal Immission Control Act (Technical Instructions on Air Quality Control - TA Luft) of 24 July 2002]

9. $39 \mathrm{BImSchV}(2010,2018)$ Neununddreißigste Verordnung zur Durchführung des Bundes-Immissionsschutzgesetzes Verordnung über Luftqualitätsstandards und Emissionshöchstmengen vom 2. August 2010, zuletzt geändert durch Art. 2 V v. 18.7.2018 I 1222 [Thirty-ninth Ordinance for the Implementation of the Federal Immission Control Act Ordinance on Air Quality Standards and Emission Ceilings of 2 August 2010. BGBI. I S. 1065, last amended by Article 2 of the Ordinance of 18 July 2018 (BGBI. I S. 1222)]

10. EU (2008a) Richtlinie 2008/50/EG des Europäischen Parlaments und des Rates vom 21. Mai 2008 über Luftqualität und saubere Luft für Europa [Directive 2008/50/EC of the European Parliament and of the Council of 21 May 2008 on ambient air quality and cleaner air for Europe]. Amtsblatt der Europäischen Union L 152/1 vom 11.06.2008

11. EU (2008b) Richtlinie 2008/1/EG des Europäischen Parlaments und des Rates vom 15. Januar 2008 über die integrierte Vermeidung und Verminderung der Umweltverschmutzung (ABI. L 24 vom 29.1.2008, S. 8)

12. EU (2004) Richtlinie 2004/107/EG des Europäischen Parlaments und des Rates vom 15. Dezember 2004 über Arsen, Cadmium, Quecksilber, Nickel und polyzyklische aromatische Kohlenwasserstoffe in der Luft [Directive 2004/107/EC of the European Parliament and of the Council of 15 December 2004 relating to arsenic, cadmium, mercury, nickel and polycyclic aromatic hydrocarbons in ambient air]. Amtsblatt der Europäischen UnionL 23 vom 26.1.2005, S. 3

13. EU (2000) Position Paper: AMBIENT AIR POLLUTION BY AS, CD AND NI COMPOUNDS. Working Group On Arsenic, Cadmium And Nickel Compounds. http://ec.europa.eu/environment/air/pdf/pp_as_cd_ni.pdf. Assessed 15 July 2015

14. EU (2010) Richtlinie 2010/75/EU des Europäischen Parlaments und des Rates vom 24. November 2010 über Industrieemissionen: Integrated Pollution Prevention and Control (IPPC) (PbEU L 334)
15. Schütze G, Hettelingh J-P (2006) Results of modelling and mapping of critical Loads of lead, cadmium and mercury and critical concentrations of mercury in precipitation and their exceedances in Europe. Sufficiency and Effectiveness Review of the heavy metals Protocol, J UNECE Reports

16. European Commission (2013) EU-Directive 2013/39/EU (Richtlinie 2013/39/EU des Europäischen Parlaments und des Rates vom 12. August 2013 zur Änderung der Richtlinien 2000/60/EG und 2008/105/EG in Bezug auf prioritäre Stoffe im Bereich der Wasserpolitik) [EU Directive 2013/39/EU (Directive 2013/39/EU of the European Parliament and of the Council of 12 August 2013 amending Directives 2000/60/EC and 2008/105/EC as regards priority substances in the field of water policy)]. J Official Journal of the European Union L 226/1

17. Schröder W, Nickel S, Jenssen M, Hofmann G, Schlutow A, Nagel H-D, Burkhard B, Dworczyk C (2019a) Anwendung des Bewertungskonzepts für die Ökosystemintegrität unter Berücksichtigung des Klimawandels in Kombination mit Stoffeinträgen [Application of the assessment concept for ecosystem integrity under consideration of climate change in combination with substance inputs]. UBA-Texte 97/2019:1-504, UBA-Texte 98/2019:1-334, UBA-Texte 99/2019, pp. 1-234

18. CLRTAP (2004) Manual on Methodologies and Criteria for Modelling and Mapping Critical Loads and Levels and Air Pollution Effects, Risks and Trends. UBA-Texte 52/2004

19. Nagel H-D, Becker R, Kraft P, Schlutow A, Schütze G, Weigelt-Kirchner R (2008) NFC Deutschland, Critical Loads, Biodiversität, Dynamische Modellierung [NFC Germany, Critical Loads, Biodiversity, Dynamic Modelling]. UBA-TEXTE 39/2008

20. CLC (2006) Karte der Bodenbedeckung [Land cover map]. CORINE Land Cover 2006. http://sia.eionet.europa.eu/CLC2006. Assessed 15 July 2015

21. BGR (Bundesanstalt für Geologie und Rohstoffe) (Ed.) (2014) Nutzungsdifferenzierte Bodenübersichtskarte 1: 1000000 (BÜK1000N) für Deutschland (Wald, Grünland, Acker) [Land use-specified soil overview map 1: 1000000 (BÜK1000N) for Germany (forest, grassland, arable land)]. Hannover, Berlin

22. Utermann J, Düwel $O$, Fuchs M (2008) Flächenrepräsentative Hintergrundwerte für As, Be Co, Mo, Sb, Se, Tl, U \& V in Böden Deutschlands aus länderübergreifender Sicht [Area-representative background values for As, Be Co, Mo, Sb, Se, TI, U \& V in German soils from a cross-state perspective]. Archiv Nr. 10040(08):1-71

23. DWD - Deutscher Wetterdienst (DWD) (2012a) Mittlere Tagesmitteltemperatur der Referenzperiode 1981-2010 für Sommer und Winter. Rasterdatei [Average daily mean temperature of the reference period 1981-2010 for summer and winter. Raster file]. Offenbach

24. DWD - Deutscher Wetterdienst (DWD) (2012b) Mittlere Jahressumme des Niederschlages in der Referenzperiode 1981-2010 für Sommer und Winter. Rasterdatei [Average annual sum of precipitation in the reference period 1981-2010 for summer and winter. Raster file.]. Offenbach

25. BGR (Bundesanstalt für Geologie und Rohstoffe) (Ed.) (2004) Landnutzungsdifferenzierte mittlere jährliche Sickerwasserrate aus dem Boden. Bereitstellung digitaler Daten [Land use-specified mean annual leachate rate from the soil. Provision of digital data]. Hannover, Berlin

26. BMVBS - Bundesministerium für Verkehr, Bauwesen und Städtebau (2013) Untersuchung und Bewertung von straßenverkehrsbedingten Nährstoffeinträgen in empfindliche Biotope [Investigation and evaluation of road traffic induced nutrient inputs into sensitive biotopes]. Endbericht zum FE-Vorhaben 84.0102/2009 im Auftrag der Bundesanstalt für Straßenwesen, verfasst von Balla S, Uhl R, Schlutow A, Lorentz $H_{t}$ Scheuschner Th. Forschung Straßenbau und Straßenverkehrstechnik, Heft 1099, BMVBS Abteilung Straßenbau, Bonn: 1-362

27. Schlutow, A., Bouwer, Y., Nagel, H.-D. (2018): Bereitstellung der Critical Load Daten für den Call for Data 2015-2017 des Coordination Centre for Effects im Rahmen der Berichtspflich-ten Deutsch-lands für die Konvention über weitreichende grenz-überschreitende Luft-verunreinigungen (CLRTAP). Im Auftrag des UBA, Abschlussbericht Projekt-Nr. UBA/43848. [Provision of critical load data for the Call for Data 2015-2017 of the Coordination Centre for Effects within the framework of the reporting obligations of Germany for the Convention on Long-Range Transboundary Air Pollution (CLRTAP). Commissioned by UBA, Final Report Project No. UBA/43848.] https://www.umweltbundesamt.de/publikationen/criti cal-load-daten-fuer-die-berichterstattung-2015. Assessed 8 April 2018 
28. Federal Statistical Office (2014) Subject-matter series 3. Series 3.2.1 Agriculture, forestry and fisheries. Growth and harvest - Field crops. Wiesbaden

29. CLRTAP (2014) Guidance on mapping concentrations levels and deposition levels, Manual on methodologies and criteria for modelling and mapping critical loads and levels and air pollution effects, risks and trends. UNECE Convention on Long-range Transboundary Air Pollution. Online-Version under www.icpmapping.org. Assessed 15 July 2015

30. CLRTAP (2017) Revision of guidance on mapping concentrations levels and deposition levels, Manual on methodologies and criteria for modelling and mapping critical loads and levels and air pollution effects, risks and trends. UNECE Convention on Long-range Transboundary Air Pollution. Online-Version unter www.icpmapping.org. Assessed 28 March 2017

31. EP CL(HM) (2008) Expert Panel on Critical Loads of Heavy Metals: $23-25$ January 2005, in Dietrich-Bonhoeffer-Haus in Berlin. Minutes in Nagel et al. 2008

32. Jacobsen C, Rademacher P, Meesenburg H, Meiwes KJ (2002) ElementGehalte in Baum-Kompartimenten: Literatur-Studie und Datensammlung [Element contents in tree compartments: Literature Study and Data Collection]. Göttingen: Niedersächsische Forstliche Versuchsanstalt, J Report, pp 1-80

33. Reinds GJ, Groenenberg JE, De Vries WD (2006) Critical Loads of Copper, Nickel, Zinc, Arsenic, Chromium and Selenium for Terrestrial Ecosystems at a European Scale. A Preliminary Assessment. J Alterra-rapport, Alterra, Wageningen

34. BGR (Bundesanstalt für Geologie und Rohstoffe) (Ed.) (2013) Karte des ackerbaulichen Ertragspotentials der Böden in Deutschland auf der Basis der BÜK1000N [Map of the arable yield potential of soils in Germany based on the BÜK1000N]. URL: http://www.bgr.bund.de/DE/Themen/ Boden/Ressourcenbewertung-management/Ertragspotential/Ertragspot ential_node.html). Assessed 28 March 2017

35. Mueller L, Schindler U, Behrendt A, Eulenstein F, Dannowski R (2007) The Muencheberg Soil Quality Rating (SQR). http://www.zalf.de/de/forsc hung/institute/Iwh/mitarbeiter/Imueller/Documents/field_mueller.pdf

36. Köstler J N, Brückner E, Bibelriether H (1968) Die Wurzeln der Waldbäume [The roots of the forest trees]. Verlag Paul Parey, Hamburg und Berlin. 284 $S$

37. WHO (2004b) Guidelines for drinking water quality. 3. ed., reprinted edn, Geneva XXIII

38. BTrinkwV (2001) (Bundes-Trinkwasserverordnung) BGBI. I S. 2977: Verordnung über die Qualität von Wasser für den menschlichen Gebrauch [Regulation on the quality of water intended for human consumption], zuletzt geändert durch Artikel 4 Absatz 22 des Gesetzes vom 7. August 2013 (BGBI. I S. 3154)

39. Römpkens PFAM, Groenenberg JE, Bonten LTC, De Vries W, Bril J (2004) Derivation of Partition Relationships to Calculate $\mathrm{Cd}, \mathrm{Cu}, \mathrm{Ni}, \mathrm{Pb}$ and $\mathrm{Zn}$ Solubility and Activity in Soil Solutions. Alterra, Wageningen. J Alterra report

40. Hettelingh JP, Sliggers J, Bolcher MVH, Gon HDvd, Groenenberg BJ, Ilyin I (2007) Heavy Metal Emissions, Depositions, Critical Loads and Exceedances in Europe

41. De Vries W, Posch M, Sverdrup HU, Larssen T, De Wit HA, Bobbink R, Hettelingh J-P (2015) Geochemical Indicators for Use in the Computation of Critical Loads and Dynamic Risk Assessments (Kapitel 2). In: DeVries W, Posch M, Hettelingh J-P (Ed.) (2015) Critical Loads and Dynamic Risk Assessments - Nitrogen, Acidity and Metals in Terrestrial and Aquatic Ecosystems. Springer Science + Business Media Dordrecht. pp 27-36

42. Lofts S, Spurgeon DJ, Svendsen C, Tipping E (2004) Deriving soil critical limits for $\mathrm{Cu}, \mathrm{Zn}, \mathrm{Cd}$, and $\mathrm{Pb}$ : a method based on free ion concentrations. J Environ Sci Technol 38(13):3623-3631

43. Tipping E, Lofts S, Hooper H, Fey B, Spugeon D, Svendsen C (2010) Critical Limits for $\mathrm{Hg}(\mathrm{II})$ in soils, derived from chronic toxicity data. J Environ Pollut 158:2465-2471

44. Tipping E, Rothwell JJ, Shotbolt L, Lawlor AJ (2010) Dynamic modelling of atmospherically-deposited $\mathrm{Ni}, \mathrm{Cu}, \mathrm{Zn}, \mathrm{Cd}$ and $\mathrm{Pb}$ in Pennine catchments (northern England). J Environ Pollut 158:1521-1529

45. AG Boden (Arbeitsgruppe Boden) (2005) Bodenkundliche Kartieranleitung [Soil mapping guide]. 5. Auflage, Bundesanstalt für Geowissenschaften und Rohstoffe und den Geologischen Landesämtern der Bundesrepublik Deutschland (Ed.), Hannover
46. De Vries W, Schütze G, Lofts S, Tipping E, Meili M, Groenenberg J, Römkens PFAM (2005) Calculation of critical loads for cadmium, lead and mercury. Background document to Mapping Manual Chapter 5(5):1-143

47. Meili M, Åkerblom S, Bringmark L, Johansson K, Munthe J (2003a) Critical loads and limits of heavy metals in ecosystems: Some Swedish contributions to European modelling efforts. Background document contributed to the Editorial Meeting of the Expert Panel on Critical Loads of Heavy Metals under UNECE-CLRTAP-ICP Modelling and Mapping, Paris, 9-10 April 2003

48. Åkerblom S, Meili M, Bringmark L, Johansson K, Berggren Kleja D, Bergvist B (2006) Partitioning of Hg between Solid and Dissolved Organic Matter in Mor Layers. In: Akerblom S (2006) Anthropogenic Heavy Metals in Organic Forest Layers. Distribution, Microbial Risk Assessment and Hg Mobility, Doctoral Thesis No. 2006:67, IV Faculty of Natural Resources and Agricultural Sciences, Swedish University of Agricultural Sciences, Uppsala, Sweden, Acta Universitatis Agriculturae Sueciae: 1-122

49. Meili M, Bishop K, Bringmark L, Johansson K, Munthe J, Sverdrup H, De Vries W (2003) Critical levels of atmospheric pollution: criteria and concepts for operational modelling of mercury in forest and lake ecosystems. J Sci Total Environ 304(1-3):83-106

50. Doyle PJ, Gutzman DW, Sheppard MI, Sheppard SC, Bird GA, Hrebenyk D (2003) An ecological risk assessment of air emissions of trace metals from copper and zinc production facilities. J Hum Ecol Risk Assess 9:607-636

51. De Vries W, Lofts S, Tipping E, Meili M, Groenenberg J, Schütze G (2007) Impact of soil Properties on critical concentrations of Cadmium, Lead, Copper, Zinc, and Mercury in soil and soil solution in view of ecotoxicological effects. Reviews of Environmental Contamination and Toxicology. Springer, New York, pp 47-89

52. GdCh (2000) Anforderungen an physikalisch-chemische und biologische Testmethoden zur Einschätzung von Böden und Bodensubstraten. Monographie Band 20 (2000). Ein Leitfaden des AK"Bodenchemie und Bodenökologie" der Fachgruppe Umweltchemie und Ökotoxikologie" unter Mitwirkung des GDCh-Beratergremiums für Altstoffe (BUA) [Requirements for physico-chemical and biological test methods for the assessment of soils and soil substrates. Monograph Volume 20 (2000). A guideline of the Working Group "Soil Chemistry and Soil Ecology" of the Division Environmental Chemistry and Ecotoxicology" with the participation of the GDCh Advisory Board for Existing Chemicals (BUA)]. Frankfurt am Main

53. Luthardt $\mathrm{V}$, Brauner $\mathrm{O}$, Hoffmann $\mathrm{C}$, Haggenmüller K (2008) Lebensräume im Wandel. J Jahresbericht der ökosystemaren Umweltbeobachtung (ÖUB) zum Offenland des Biosphärenreservates Flusslandschaft Elbe und des Biosphärenreservates Schorfheide-Chorin: Zeitreihenuntersuchungen des Mineralischen Graslandes und des entwässerten, landwirtschaftlich genutzten und aufgelassenen Moorgraslandes (zzgl. 3-jährige Parameter der naturnahen Moore im BR SC) [Changing habitats. Annual report of the Ecosystem Environmental Observatory (ÖUB) on the open land of the biosphere reserves Flusslandschaft Elbe and Schorfheide-Chorin: Time series studies of the mineral grassland and the drained, agriculturally used and abandoned moor grassland (plus 3-year parameters of the near-natural moors in BR SC)]. Fachhochschule Eberswalde - Fachbereich Landschaftsnutzung und Naturschutz. http:// lanuweb.fh-eberswalde.de/oeub/pdf/OeUB Bericht_2008.pdf. Assessed 15 July 2015

54. Knappe F, Möhler S, Ostermayer A, Lazar S, Kaufmann C (2008) Vergleichende Auswertung von Stoffeinträgen in Böden über verschiedene Eintragspfade [Comparative evaluation of substance inputs into soils via different input paths]. UBA-Texte 36(08):1-410

55. Nagel H-D, Becker R, Eitner H, Kunze F, Schlutow A, Schütze G (2000) Kartierung von Critical Loads für den Eintrag von Säure und eutrophierenden Stickstoff in Waldökosysteme und naturnahe waldfreie Ökosysteme zur Unterstützung von UNECE-Protokollen [Mapping of critical loads for the input of acidity and eutrophying nitrogen into forest ecosystems and semi-natural forest-free ecosystems in support of UNECE protocols]. Umweltbundesamt, UBA-FE-Bericht 297(73):011

56. Nagel H-D, Schütze G (1998) Kriterien für die Erarbeitung von Immissionsminderungszielen zum Schutz der Böden und Abschätzung der langfristigen räumlichen Auswir $\neg$ kun $\neg$ gen anthropogener Stoffeinträge auf die Bodenfunktionen [Criteria for the development of immission reduction targets for soil protection and estimation of the long-term spatial effects of anthropogenic substance inputs on soil functions]. UBA-Texte 19/1998 
57. Sauerbeck D, Styperek P (1988) Schadstoffe im Boden, insbesondere Schwermetalle und organische Schadstoffe aus langjähriger Anwendung von Siedlungsabfällen [Pollutants in the soil, especially heavy metals and organic pollutants from long-term use of municipal waste]. UBA-Texte $16 / 1988$

58. LUA NRW (1996) Landesumweltamt Nordrhein-Westfalen: Daten zum Schwermetallgehalt landwirtschaftlicher Kulturpflanzen aus Erhebungsuntersuchungen in Nordrhein-Westfalen (Kontrollflächen) [Data on the heavy metal content of agricultural crops from survey studies in North Rhine-Westphalia (control areas)]. Düsseldorf

59. Bergkvist B, Folkeson L, Berggren D (1989) Fluxes of Cu, Zn, Pb, Cd, Cr and $\mathrm{Ni}$ in temperate forest ecosystems. J Water, Air, and Soil Pollution 47(217):286

60. Wiersma D, van Goor BJ, van der Veen NG (1986) Cadmium, lead, mercury and arsenic concentrations in crops and corresponding soils in the Netherlands. J Agric Food Chem 34:1067-1075

61. Van Driel W, Stuurmans W, Dekkers JMJ, De Vries W, Vos G, Stienen MJJ (1986) Zware metalen in oevergronden en daarop verbouwde gewassen in het stroomgebied van Maas, Geul en Roer in de provincie Limburg. 1. Algemene gegevens en samenvatting van de resultaten. Rapport von de projectgroep zware metalen in oevergronden van Maas en zijrivieren

62. MUGV Brandenburg - Ministerium für Umwelt, Gesundheit und Verbraucherschutz (2009) Mittlere Abflussspende für die Zeitreihe 1976-2005 (Abimo 2.1) [Mean leaching donation for the time series 1976-2005 (Abimo 2.1)]. URL: http://www.mugv.brandenburg.de/lua/gis/ wh_abimo.zip. Assessed 8 April 2014

63. Landesbetrieb für Hochwasserschutz und Wasserwirtschaft - LHW Sachsen-Anhalt (2004) (Ed.) Ermittlung der potentiellen diffusen Nährstoffeinträge (Emission N u. P) in Oberflächengewässer des Landes Sachsen-Anhalt auf Basis der Wasserkörper gemäß Anhang II EU - WRRL. Projektteil 2: Abschätzung der dränierten Fläche im Land Sachsen - Anhalt als Grundlage zur Berechnung des Dränwasserabflusses [Determination of the potential diffuse nutrient inputs (emission $N$ and $P$ ) into surface waters of the State of Saxony-Anhalt on the basis of the water bodies according to Annex II EU - WFD. Project part 2: Estimation of the drained area in the State of Saxony - Anhalt as a basis for the calculation of drainage water leaching]. Abschlussbericht Landesbetrieb für Hochwasserschutz und Wasserwirtschaft Sachsen-Anhalt. Magdeburg

64. LAWA (2004) Ableitung von Geringfügigkeitsschwellenwerten für das Grundwasser [Derivation of negligibility thresholds for groundwater]. Länderarbeitsgemeinschaft Wasser (Ed.), Düsseldorf, 2004, S. 33. http:// www.lawa.de/documents/GFSBericht-DE_a8c.pdf. Assessed 15 July 2015

65. Zeddel A, Quadflieg A, Utermann J (2016) Grundsätze für die Anwendung der Geringfügigkeitsschwellen an der Schnittstelle Wasserrecht - Abfallrecht - Bodenschutzrecht [Principles for the application of de minimis thresholds at the interface of water law - waste law - soil protection law]. J Recht/Strategie/Wirtschaft. http://vivis.de/phocadownload/2016_ mna/2016_MNA_051-64_Zeddel.pdf. Assessed 28 Mar 2017

66. Kalbitz K, Zuber T, Park HJ, Matzner E (2004) Environmental Controls on Concentrations and Fluxes of Dissolved Organic Matter in the Forest Floor and in Soil Solution. In: Matzner, E. (Ed.): Biochemistry of Forested Catchments in a Changing Environment. Ecological Studies 172, Springer, Berlin Heidelberg, pp 315-337

67. Wiedemann F (1943) Ertragstafeln der Kiefer [Yield tables of the pine tree]. In: Schober, R. (1975) Ertragstafeln wichtiger Baumarten bei verschiedenen Durchforstungen [Yield tables of important tree species in various thinnings]. Frankfurt a. M, Verlag Sauerländer

68. Wiedemann F (1936) Ertragstafeln der Fichte [Yield tables of the spruce]. In: Schober, R. (1975) Ertragstafeln wichtiger Baumarten bei verschiedenen Durchforstungen [Yield tables of important tree species in various thinnings]. Frankfurt a. M.: Verlag Sauerländer

69. Schober R (1967) Weißtanne, Europäische Lärche und Rotbuche [Silver fir, European larch and red beech]. In: Schober R (1975) Ertragstafeln wichtiger Baumarten bei verschiedenen Durchforstungen [Yield tables of important tree species in various thinnings]. J. D. Sauerländer's Verlag, Frankfurt a. M

70. Mitscherlich G (1950) Die Bedeutung der Wuchsgebiete für das Bestandeswachstum von Buche, Eiche, Erle und Birke [The importance of the growing areas for the growth of beech, oak, alder and birch]. J Forstwirtschaftliches Zentralblatt 69:148-211
71. Schwappach H (1912) Ertrags-Schätztafeln für Forstbestände [Yield estimation tables for forest stands]. J Archiv der Forstwissenschaft Eberswalde

72. Schober R (1975) Ertragstafeln wichtiger Baumarten bei verschiedenen Durchforstungen.[Yield tables of important tree species in various thinnings] J. D. Sauerländer's Verlag, Frankfurt a. M

73. Wimmenauer K (1919) Wachstum und Ertrag der Esche [Growth and yield of ash]. AFJZ 9-17:37-40

74. Erteld W (1962) Ertragstafelauszüge für den Gebrauch in der Praxis [Yield table extracts for use in practice]. Neumann-Verlag

75. Böckmann T (1990) Wachstum und Ertrag der Winterlinde (Tilia cordata Mill) in Nordwestdeutschland [Growth and yield of the winter linden (Tilia cordata Mill) in northwest Germany.]. Dissertation Univ. Göttingen

76. Schober R (1987) Ertragstafeln wichtiger Baumarten [Yield tables of important tree species]. Sauerländer's Verlag, Frankfurt

77. Knapp E (1973) Ertragstafeln für Schwarzpappelsorten [Yield tables for black poplar varieties]. Forschungsbericht des Instituts für Rohholzerzeugung Abt. Waldbau/Ertragskunde, Eberswalde

78. Bobbink R, Hettelingh JP (Eds.) (2011) Review and revision of empirical critical loads and dose-response relationships. Proceedings of an expert workshop, Noordwijkerhout, 23-25 June 2010. Coordination Centre for Effects, RIVM, NL. http://www.b-ware.eu/sites/default/files/publicaties/ Review-revision-empirical-critical-loads-2011.pdf. Assessed 15 July 2015

79. Bohner A, Eder G, Schink M (2007) Nährstoffkreislauf und Stofflüsse in einem Grünland-Ökosystem [Nutrient cycling and material flows in a grassland ecosystem.]. Bericht HBLFA Raumberg-Gumpenstein, 12. Gumpensteiner Lysimetertagung. pp 91-99

80. Bolte A (2006) Biomasse- und Elementvorräte der Bodenvegetation auf Flächen des forstlichen Umweltmonitorings in Rheinland-Pfalz [Biomass and element stocks of ground vegetation on areas of forest environmental monitoring in Rhineland-Palatinate]. J Berichte des Forschungszentrums Waldökosysteme, Reihe B, Bd. 72, Göttingen, 29 S. + Anhänge

81. Brenner S, Pfeffer E, Schumacher W (2004) Extensive Schafbeweidung von Magerrasen im Hinblick auf Nährstoffentzug und Futterselektion [Extensive sheep grazing of low-nutrient grassland for nutrient removal and feed selection.]. J Natur Landschaft 4:167-174

82. Briemle G, Eickhoff D, Wolf R (1991) Mindestpflege und Mindestnutzung unterschiedlicher Grünlandtypen aus landschaftsökologischer und landeskultureller Sicht [Minimum maintenance and minimum use of different types of grassland from a landscape ecology and culture perspective]. Landesanstalt für Umweltschutz Baden-Württemberg und Staatliche Lehr- und Versuchsanstalt für Viehhaltung und Grünlandwirtschaft (LVGG) (Ed.). Beiheft 60 zu den J Veröffentl. für Naturschutz und Landschaftspflege in Baden-Württemberg. Karlsruhe. pp 1-160

83. Brünner F, Schöllhorn J (1972) Bewirtschaftung von Wiesen und Weiden [Management of meadows and pastures]. 2., umgearb. u. erw. Aufl.. Verlag Eugen Ulmer, Stuttgart. pp 1-166

84. Dierschke H, Briemle G (2008) Kulturgrasland [Cultivated grassland]. Ulmer-Verlag, Stuttgart

85. Elsäßer M (2007) Düngung von Wiesen und Weiden [Fertilisation of meadows and pastures]. In: Bildungs- und Wissenszentrum für Viehhaltung, Grünlandwirtschaft, Wild und Fischerei, Aulendorf (Ed.) (2008): J Merkblätter für die umweltgerechte Landbewirtschaftung Nr. 13, 4. Auflage

86. Keienburg T, Prüter J (Ed.) (2004) Feuer und Beweidung als Instrumente zur Erhaltung magerer Offenlandschaften in Nordwestdeutschland - Ökologische und sozioökonomische Grundlagen des Heidemanagements auf Sand- und Hochmoorstandorten [Fire and Grazing as Instruments for the Conservation of Lean Open Landscapes in NorthWest Germany - Ecological and Socio-economic Principles of Heath Management on Sand and Raised Moor Sites]. NNA-Berichte (17) Heft 2 Schneverdingen, pp 1-221

87. Klapp E (1954) Wiesen und Weiden [Meadows and pastures]. 2., völlig neu gestaltete Aufl., Verlag Paul Parey, Berlin und Hamburg. $519 \mathrm{~S}$

88. Petersen A (1981) Die Gräser als Kulturpflanzen und Unkräuter auf Wiese, Weide und Acker [Grasses as crops and weeds in meadows, pastures and fields]. 5., bearb. Aufl., Akademie-Verlag, Berlin, 280 S

89. Quade J (1993) Faustzahlen für Landwirtschaft und Gartenbau [Fistfigures for agriculture and horticulture]. Hydro Agri Dülmen GmbH (Ed.), 12. überarb., erg. und erw. Aufl. Münster-Hiltrup: Landwirtschaftsverlag, pp 1-618 
90. Ruhr-Stickstoff-Aktiengesellschaft (Ed.) (1988) Faustzahlen für Landwirtschaft und Gartenbau [Fist-figures for agriculture and horticulture]. 11., überarb., erg. u. erw. Aufl.. Bochum, $587 \mathrm{~S}$

91. Stein-Bachinger K, Bachinger J, Schmitt L (2004) Nährstoffmanagement im Ökologischen Landbau [Nutrient management in organic farming]. J Kuratorium für Technik und Bauwesen in der Landwirtschaft e.V. (KTBL) (Ed.). Darmstadt, $136 \mathrm{~S}$

92. Tischew S (2011) Management von Offenland-Lebensräumen an pflegeproblematischen Steilhängen durch Ziegen [Management of open land habitats on steep slopes by goats]. http://www.loel.hs-anhal t.de/forschung/forschungsprojekte.html? tx_bwhsaresearchdb_pi1. cmd] = projekt_lesen\&tx_bwhsaresearchdb_pi1. person] $=24017 \&$ tx bwhsaresearchdb_pi1. projekt_id] $=14139 \& \mathrm{cHash}=3 \mathrm{bf21fec3c4ffa-}$ 27448d713a3efaa151. Assessed 15 July 2015

93. WHO (2011) Guidelines for drinking-water quality, 4th edn. World Health Organization, Geneva, p 632

94. EPA (2014) Drinking Water Contaminants - Inorganic. http://water.epa. gov/drink/contaminants/index.cfm\#Inorganic
95. Health Canada (2012) Guidelines for Canadian Drinking Water Quality - Summary Table. Water, Air and Climate Change Bureau, Healthy Environments and Consumer Safety Branch, Health Canada, F.-P.-T.C.o.D.W.o.t.F.-P.T.C.o.H.a.t. J Environment, Ottawa, Ontario, pp 1-22

96. Crommentuijn T, Polder MD, van de Plassche EJ (1997) Maximum Permissible Concentrations and Neglectible Concentrations for metals, taking Background concentrations into account, National Institut of Public Health and Environment, Bilthoven, Netherlands. J Report Nr. 601501:001

97. Tipping E (2014) Ergebnisse der mit dem WHAM-Modell berechneten Critical Limits für die in Deutschland vorkommenden Rezeptortypen [Results of the critical limits calculated with the WHAM model for the receptor types occurring in Germany]. Excel-Tabelle per Email

\section{Publisher's Note}

Springer Nature remains neutral with regard to jurisdictional claims in published maps and institutional affiliations.

\section{Submit your manuscript to a SpringerOpen ${ }^{\circ}$ journal and benefit from:}

- Convenient online submission

- Rigorous peer review

- Open access: articles freely available online

- High visibility within the field

- Retaining the copyright to your article

Submit your next manuscript at $\boldsymbol{\nabla}$ springeropen.com 